FIU Law Review

Volume 1

Number 1 Inaugural Issue

Article 12

Spring 2006

\title{
Why the Limited Liability Company Should Sound the Death Knell of the Application of the "Nexus of Contracts" Theory to Corporations
}

Brian Dean Abramson

Follow this and additional works at: https://ecollections.law.fiu.edu/lawreview

Part of the Other Law Commons

Online ISSN: 2643-7759

\section{Recommended Citation}

Brian D. Abramson, Why the Limited Liability Company Should Sound the Death Knell of the Application of the "Nexus of Contracts" Theory to Corporations, 1 FIU L. Rev. 185 (2006).

DOI: https://dx.doi.org/10.25148/lawrev.1.1.12

This Comment is brought to you for free and open access by eCollections. It has been accepted for inclusion in FIU Law Review by an authorized editor of eCollections. For more information, please contact lisdavis@fiu.edu. 


\title{
Why the Limited Liability Company Should Sound the Death Knell of the Application of the "Nexus of Contracts" Theory to Corporations
}

\author{
Brian Dean Abramson ${ }^{\dagger}$
}

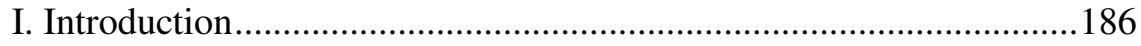

II. Theories of the Firm: Fiduciary Duties, and the Nexus of

Contracts

A. How the Development of the Modern Corporation Has

Influenced Corporate Theory

1. Entity versus Aggregate

2. Artificial versus Natural Creation.

3. Public Interest versus Private Concern..................................193

B. A Brief History of Ideas of the Corporation .................................193

C. The Jurisprudence of Fiduciary Duties......................................198

1. The Development of Corporate Fiduciary Duties ................198

2. The Nature of Corporate Fiduciary Duties............................200

D. Development of the Nexus of Contracts Theory of

Corporations................................................203

E. Application of the Nexus of Contracts Theory of Corporations by Courts ...........................................................207

III. The Development of the Limited Liability Company ......................211

A. Business Organizations Preceding the LLC ...............................211

1. The Partnership ................................................................211

2. The Limited Partnership (LP) ..........................................213

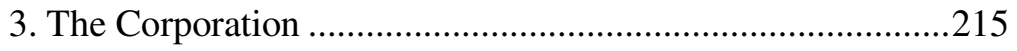

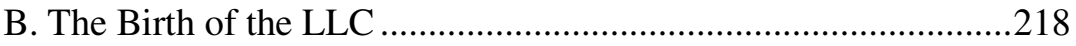

C. The Contractarian Nature of the Limited Liability Company ....224

1. Ability of Parties to Avoid Fiduciary Duties Through an

\footnotetext{
$\dagger$ J.D., Florida International University College of Law, 2005. Special thanks are due to Professor Jerry Markham, without whose guidance and inspiration this project would not have seen the light of day; to Professors Charles Pouncy and Ediberto Roman for their thoughtful remarks on my efforts, to my colleagues, Douglas Giuliano, Michael Hirschkowitz, and Mary Trachian, who supported my efforts in countless ways, and to my wife, Sara, for putting up with my labors from early in the morning until late into the night. E-mail: babramson@1fiplaw.com.
} 
LLC .224

D. Transferability of Business Forms and Recognition of Foreign LLCs.... 230

IV. Implications of the Limited Liability Company for the Legal Status of Corporations.........................................231

A. All Business Organizations Are Cost Avoidance Systems .........232

B. Parties Who Now Choose to Form a Corporation Instead of a Limited Liability Company Have Chosen to Accept the Associated Fiduciary Duties .......................................235

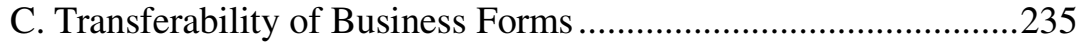

D. Irrelevance of the Actual Nature of the LLC.............................236

V. Conclusion ...................................................................................237

\section{INTRODUCTION}

Surprisingly, no one has yet examined the possibility that the existence of a fairly new and highly flexible business form, the limited liability company (hereinafter LLC), might have a negative effect on the application of the nexus of contracts theory to corporations. ${ }^{1}$ Widely debated by scholars of law and economics since the late $1970 \mathrm{~s}^{2}$, this concept posits that the cor-

\footnotetext{
${ }^{1}$ A considerable volume of research and writing has been done on both the nexus of contracts theory and the LLC. Some authors suggest that the application or non-application of the nexus of contracts theory should be identical to all business forms. See, e.g., Frank H. EASTERBrook \& Daniel R. Fischel, THE ECONOMIC STRUCTURE OF CORPORATE LAW 251 (1991) [hereinafter, EASTERBRoOK \& FISCHEL] (suggesting that courts assessing both corporations and partnerships should use as a default the likely intent of the parties, had they considered the point of dispute). Other authors use the unique set of characteristics enjoyed by the LLC to posit that the LLC is an effective contractarian business form, and that the success of the LLC might promote the application of contractarian principles to corporations as well. See, e.g., Larry E. Ribstein, Limited Liability and Theories of the Corporation, 50 MD. L. REV. 80 (1991) [hereinafter Ribstein, Limited Liability] (asserting that "the business trust and limited liability company statutes may be intermediate steps on the road to full recognition of private [contractarian] ordering, just as special chartering was an intermediate step toward the development of general incorporation statutes"). $I d$. at 126 . No commentator has suggested that the nexus of contracts theory might validly be applied to the LLC and yet remain invalid with respect to corporations. In all fairness to these authors, it must be conceded that many of the seminal writings on the nexus of contracts theory were produced before the LLC developed widespread popularity. The earliest direct discussion of the application of the nexus of contracts theory to the limited liability company appears to have occurred in a 1992 comment, Jim Hyde, Comment, Constitutionally Mandated Fairness and the Limited Liability Company: An Argument for the Extra-Territorial Application of Limited Liability Company Statutes, 1 GEO. MASON L. REV. 83 (1992) (arguing for recognition in all states of the limited liability inherent to LLCs formed in any state, based on the contractual nature of the entity combined with full faith and credit principles). Id. at 95-96.

2 See infra notes 143-49 and accompanying text for further discussion of the amount of commentary generated by proponents and opponents of the nexus of contracts theory; see also Jonathan C. Lipson, Directors' Duties to Creditors: Power Imbalance and the Financially Distressed Corporation, 50 UCLA L. REv. 1189, 1192 (2003) (describing the debate over the nexus of contracts theory as "the
} 
poration should be treated as a collection of contracts between interested parties. ${ }^{3}$ By contrast, the longstanding practice of judges has been to create and impose fiduciary duties - heightened standards of behavior-on corporate managers, ${ }^{4}$ irrespective of any contractual arrangements between the parties working for or within the corporation. ${ }^{5}$

Such court-imposed standards go far beyond the basic contractual requirement of good faith and fair dealing. ${ }^{6}$ Certain fiduciary duties-such as the manager's duty not to compete in business against his or her own corporation-can never be waived, even with the prior consent of both owners and managers of the corporation. ${ }^{7}$ Advocates of the nexus of contracts theory, or contractarians, ${ }^{8}$ argue that the existing regime of mandatory fiduci-

principal corporate law discussion of the last twenty years"); Andrew D. Shaffer, LL.M. Thesis, Corporate Fiduciary-Insolvent: The Fiduciary Relationship Your Corporate Law Professor (Should Have) Warned You About, 8 AM. BANKR. INST. L. REv. 479, 483 n.12 (2000) (stating that "[a]n academic holy war exists over whether the fiduciary concept can be explained purely in terms of contract, or whether fiduciary relationship represents something more").

3 See infra notes 110-59 and accompanying text for discussion of the nexus of contracts theory of corporations.

4 Following the example of David Millon, Theories of the Corporation, 1990 DuKE L.J. 201 (1990), I note here that "the terms 'management' or 'managers' refer collectively to the corporation's board of directors and senior officers." $I d$. at 201 n.1.

5 See infra notes 80-109 and accompanying text for discussion of the existing regime of fiduciary duties.

6 See infra notes 91-92 and accompanying text.

7 See infra notes 101-109 and accompanying text for discussion of the waivability of fiduciary duties. Because corporations exist and operate in accordance with state statutes, it is, of course, within the power of state legislatures to explicitly eliminate fiduciary duties, or to make such duties optional provisions. Indeed many states have taken a small step in this direction by enacting statutes which allow corporate shareholders to waive the right to damages for breach of the duty of care normally owed by directors. See Fred S. McChesney, Legal Change and Small Business Law, 1 J. SMaLl \& EMERGING Bus. L. 1, 8 (1997) (stating that "Delaware statutorily allows shareholders to waive, with some minor exceptions, any duty of care they might otherwise be owed by their directors, as does the Model Business Corporation Act"); Robert B. Thompson, The Law's Limits on Contracts in a Corporation, $15 \mathrm{~J}$. CORP. L. 377, 406 (1990) (noting that "[s]ince Delaware's initial legislation on this subject in 1986, four-fifths of the states have added this option to their corporation statutes"). No state has yet made a similar allowance for waiver of damages liability for a breach the duty of loyalty. Neither has any state eliminated any of the commonly assessed fiduciary duties outright.

8 Columbia University Professor John C. Coffee, Jr., appears to have been the first author to apply the term "contractarian" to proponents of the nexus of contracts theory of corporations. See John C. Coffee, Jr., The Mandatory/Enabling Balance in Corporate Law: An Essay on the Judicial Role, 89 Colum. L. Rev. 1618 (1989). The term itself has long enjoyed a broader application to those theorists who believe that society as a whole constitutes a social contract, or that the government of the United States constitutes a form of contract with the people. See, e.g., Nickolai G. Levin, Constitutional Statutory Synthesis, 54 ALA. L. REV. 1281 (2003) (examining the "contractarian" underpinnings of the Constitution's separation of powers). This usage is discussed in EASTERBROOK \& FISCHEL, supra note 1, at 15 , who conclude that the arguments in favor of the existence of the 'social contracts' are, in fact, weaker than those supporting the nexus of contracts theory of corporations simply because "[t]he corporate venture has many real contracts." Id. at 16 (emphasis added). Naturally, the ideological opponents of contractarians are generally referred to as "anti-contractarians"; see, e.g., Coffee at 1619; Henry N. 
ary duties should be eliminated, and that the law of contract should serve as the sole touchstone for determining what responsibilities corporate managers owe to owners. ${ }^{9}$ Contractarians assert that if owners and managers were required to memorialize the duties owed by the latter to the former, then market forces would compel these parties to voluntarily arrive at a set of duties that maximize efficiency for the corporation and accountability to the shareholders. ${ }^{10}$

This comment will argue that application of the nexus of contracts theory to corporations has been undercut by the existence of the LLC. It first examines the historical foundations and current conditions of both the nexus of contracts theory, and of the judicial application of the fiduciary duties that contractarians would relegate to contractual gap-fillers. ${ }^{11}$ The various arguments raised by proponents of this theory are examined, ${ }^{12}$ and the failure of this theory to affect the jurisprudence of fiduciary duties is discussed. ${ }^{13}$ A similar examination follows of the historical foundations of the limited liability company and explains the course of its development, after a faltering start, into one of the most popular business forms. ${ }^{14}$ The different approaches taken by state legislatures and courts highlight the flexibility of this business form, ${ }^{15}$ and underscore how it is readily described as an actual nexus of contracts. ${ }^{16}$ Finally, this comment analyzes the impact of the LLC on the ongoing debate between contractarians and anticontractarians, and the particular debate among scholars and in the courts over the ability of LLC members to waive fiduciary duties. In conclusion, it reiterates and supports the arguments for the existence of the LLC undermining application of the nexus of contracts theory to corporations.

Butler \& Larry E. Ribstein, Opting Out of Fiduciary Duties: A Response to the Anti-Contractarians, 65 WASH. L. REV. 1, 3 (1990).

9 See infra notes 110-111, 133-142 and accompanying text for discussion of waiver of duties under contractarian theory.

10 See generally Michael C. Jensen \& William H. Meckling, The Theory of the Firm: Managerial Behavior, Agency Costs, and Ownership Structure, 3 J. FIN. Econ. 305 (1976) available at http://www.sciences-sociales.ens.fr/ adirer/textes/Jensen-Meckling.pdf (last visited March 8, 2004). See also EASTERBROOK \& FISCHEL, supra note 1, at 12-22.

11 See, e.g., EASTERBROOK \& FISCHEL, supra note 1, at 22.

12 See infra notes 116-127, 132-142 and accompanying text for discussion of the arguments raised by contractarians.

13 See infra notes 146-159 and accompanying text for discussion of the failure of courts to adopt the nexus of contracts theory, and the possibility that this theory may be judicially or legislatively adopted in the future.

14 See infra notes 190-226 and accompanying text for discussion of the creation and growing popularity of the LLC.

15 See infra notes 189-209, 241-272 and accompanying text for discussion of the various legislative and judicial actions taken with respect to the LLC.

16 See infra notes 227-272 and accompanying text for discussion of the contractarian nature of the LLC. 


\section{THEORIES OF THE FIRM: FIDUCIARY DUTIES, AND THE NEXUS OF CONTRACTS}

\section{A. How the Development of the Modern Corporation Has Influenced Corporate Theory}

Corporate theory, policy, and practice constitute a never-ending circle of influences. Theories devised by economists and legal scholars to explain or justify the nature of business organizations influence the policy decisions made by courts, legislatures, and enforcement agencies. ${ }^{17}$ Practical concerns about the way the law ought to treat corporate activity have been influenced by "various theories of the corporation that have enjoyed prominence since the 19th century." It has been noted that "particular theories of the corporation are perceived to justify particular legal rules or, at a more general level, a particular approach to regulation of business activity." ${ }^{, 19}$ Policy decisions, in turn, may lead to changes in the way business organizations operate in practice, as they strive to avoid costly legal conflicts, and perhaps to take advantage of perceived loopholes. ${ }^{20}$ These operational changes then lead to new theories, starting the cycle over again.

17 There have, however, always been a number of competing theories in play at any one time. As one commentator explains:

American attitudes toward commerce and centralized accumulations of wealth have evolved over the years, but at no time has there been a single overarching attitude toward them. American political culture contains a number of differing political and social traditions (e.g., liberalism, civic republicanism, dissenting Protestantism) that have been woven together in the documents and ideas that make up our common culture. However, historians have also realized that no one of these traditions has ever been completely dominant. The history of American attitudes toward state chartered business organization reflects the tension between these various traditions.

David L Cohen, Theories of the Corporation and the Limited Liability Company: How Should Courts and Legislatures Articulate Rules for Piercing the Veil, Fiduciary Responsibility and Securities Regulation for the Limited Liability Company?, 51 OKLA. L. REV. 427, 432 (1998), citing:

Note, Incorporating the Republic: The Corporation in Antebellum Political Culture, 102 HARV. L. REV. 1883 (1989) (arguing that different visions of republicanism and emerging liberalism defined and were defined by the emergence and triumph of the private business corporation); J.C.D CLARK, THE LANGUAGE OF LIBERTY 1660-1832 (1994) (arguing for the equal importance of protoliberal, republican and dissenting Protestant traditions in forming American political thought).

$I d$. at note 5 .

18 Millon, supra note 4, at 204, stating in full, "[m]y starting point is agreement with [Morton] Horwitz that the various theories of the corporation that have enjoyed prominence since the 19th century have influenced thinking about how the law should treat corporate activity," (citing Morton Horwitz, Santa Clara Revisited: The Development of Corporate Theory, 88 W. VA. L. REV. 173, 221-22 (1985) (discussing legal theories of the corporation in the first half of the Twentieth Century)).

19 Millon, supra note 4, at 204.

20 Businesses are not neutral players in this field, and theoretical exchange and the practical experience of lawmakers are not the only drivers of change in business law. Often different parties within a particular kind of business relationship seek to better their own position through efforts to 


\section{Entity versus Aggregate}

Three dimensions have dominated theoretical discussion of the corporation. ${ }^{22}$ The first examines "the distinction between the corporation as an entity, with a real existence separate from its shareholders and other participants, and the corporation as a mere aggregation of natural individuals without a separate existence. ${ }^{, 23}$ The work of E. Merrick Dodd, Jr., ${ }^{24}$ highlights one theoretical leap made possible by the assumption that the corporation is an entity, as opposed to an aggregate, stating his belief:

... that public opinion, which ultimately makes law, has made . . . substantial strides in the direction of a view of the business corporation as an economic institution which has a social service as well as a profit-making function, that this view has already had some effect upon legal theory, and that it is likely to have a greatly increased effect upon the latter in the near future.

persuade the legislature or the judiciary; see Alliance of Automobile Manufacturers v. Gwadosky, 304 F.Supp.2d 104 (D.Me. 2004):

The public tends to see the dealer-manufacturer relationship as symbiotic and unitary: the manufacturer designs and builds vehicles; the dealer sells and repairs them, all to their greater economic advantage. Beneath the surface, however, is an uneasy, often roiling relationship. Since the parties themselves have been unable over the course of the last three decades to negotiate satisfactorily their conflicting positions in the warranty reimbursement area, they have each periodically sought to enlist the support of the legislative and judicial arms of government. Each legislative action has been followed by resort to the judicial branch, spawning new legislation and new judicial rulings, a seemingly never ending cycle, perfectly exemplified by the instant case.

Id. at 106-07.

21 The influences of Adolf A. Berle, Jr., and E. Merick Dodd, discussed infra note 24, offer a prime example of this principle at work, each having argued for a position which impacted the development of the law, and which thereby caused changes in the behavior of businesses; see also Millon, supra note 4, at 211-31 (discussing how both the entity theory and the aggregate theory of corporations have enjoyed periods of prominence, during which each influenced the development of the law, which in turn changed the behavior of corporations).

22 Millon, supra note 4.

23 Id. at 201

24 E. Merrick Dodd, Jr., achieved prominence as a theorist of corporate duties in the 1930's. Millon specifically references contentions raised in E. Merrick Dodd, Jr., For Whom Are Corporate Managers Trustees?, 45 HARV. L. REV. 1145 (1932) (asserting that fiduciary duties assessed to corporate managers should go beyond the shareholders, and should also be made protect employees and society in general). Dodd's views sparked a public dialogue regarding the duties of corporate directors between himself and Adolf A. Berle, Jr., who advocated a strict application of fiduciary duty solely for the benefit of shareholders. See, e.g., Adolf Berle \& Gardiner MeAns, The Modern Corporation AND PRIVATE PROPERTY (1932). For a more comprehensive discussion of the debate between Berle and Dodd, see A. A. Sommer, Jr., Whom Should the Corporation Serve? The Berle-Dodd Debate Revisited Sixty Years Later, 16 DEL. J. CORP. L. 33 (1991) (suggesting that the debate continues, at least in academic circles); Dalia Tsuk, Corporations Without Labor: The Politics of Progressive Corporate Law, 151 U. PA. L. REV. 1861, 1868, 1881-96 (2003) (noting that Berle's position ultimately prevailed).

25 Dodd, supra note 24, at 1148. 
Recognizing the corporation and its shareholders as separate entities enabled theorists to analyze separately the shareholders' interests, and the interests of the corporation itself. Thus is it noted that "[b]ecause management worked for the corporation, its obligations to the shareholders were, at best, secondary and indirect." ${ }^{26}$ Conflict purportedly arises when the interests of owners, who are typically passive investors, are separated from the interests of active managers. ${ }^{27}$ Adam Smith made this point eloquently well over 200 years ago:

The directors of such companies, however, being the managers rather of other people's money than of their own, it cannot well be expected, that they should watch over it with the same anxious vigilance with which the partners in a private copartnery frequently watch over their own. Like the stewards of a rich man, they are apt to consider attention to small matters as not for their master's honour, and very easily give themselves a dispensation from having it. Negligence and profusion, therefore, must always prevail, more or less, in the management of the affairs of such a company. ${ }^{28}$

Conceptually, therefore, a firm that is an independent entity creates a disconnect between the interests of shareholders and the interests of the managers. The managers are most interested in improving their own lot. ${ }^{29}$ To the extent that managers work to further the interests of the shareholders, they are motivated by their desire to strengthen their own position within the corporation itself. ${ }^{30}$

\section{Artificial versus Natural Creation}

The second distinction raised is "between the corporation as an artificial creation of state law and the corporation as a natural product of private initiative." 31 The first of these possibilities is criticized as "the so-called 'concession' theory ... that corporations are creatures or concessions of the state rather than wholly the product of private contract. ${ }^{, 32}$ Proponents of this theory pointed to the requirement that the corporation be created in

Millon, supra note 4, at 218.

See, e.g., BERLE \& MEANS, supra note 24, at 119-25.

28 Adam Smith, The Wealth of Nations: Complete and Unabridged 800 (Edwin Cannan ed., The Modern Library 2000) (1776) [hereinafter ADAM SMITH]. More recently, this sentiment has been restated in more direct language in JERRY W. MARKHAM \& THOMAS LEE HAZEN, CORPORATIONS AND OTHER BUSINESS ORGANIZATIONS 13 (2002): “The manager's quest to maximize their [own] utility does not naturally lead to decisions that also maximize the value of the firm."

29 See Jensen \& Meckling, supra note 10, at 12.

30 Id.

31 Millon, supra note 4, at 201.

32 Ribstein, Limited Liability, supra note 1, at 85. 
accordance with state law, ${ }^{33}$ and to the fact that corporations were initially chartered almost exclusively to serve purposes beneficial to the general public. $^{34}$ If corporations are indeed properly classified as creations of state law, then the benefits of incorporation can be seen as a boon from the state, which justifies any restrictions that the state may choose to impose. Berle and Means identify three such restrictions that were typically imposed on corporations:

(1) The enterprise was required to be defined and ... limited in scope. ...

(2) The contributions of capital were rigidly supervised. The corporation was not allowed to commence business until a certain amount of its shares had been "paid up." . . . [and] additional shares issued should be paid for at a fixed minimum rate.

(3) A rigid capital structure was set up.... the entire system [by which stocks were classified] had to be carefully laid out, embodied in the charter, and passed upon by the legislature.

Additional restrictions have included measures designed to protect investors in corporations engaged in particular fields of business, ${ }^{36}$ and to protect corporate employees.

If, on the other hand, corporations are the natural product of "private individuals and inevitable market forces, ${ }^{, 38}$ then the state should be no more concerned with the operation of corporations than any other relationship bottomed on contractual obligations between parties. Although the state continues to maintain an interest in the behavior of managers with respect to their shareholders, it is informative to note that the protections identified by Berle and Means have been abridged or eliminated completely. ${ }^{39}$

33 Millon, supra note 4, at 206.

34 J. HuRst, The Legitimacy of the Business CoRporation In THE LAW OF THE UNited STATES 1780-1970, at 15 (1970). Hurst expands upon this claim:

Of the 317 separate-enterprise special charters enacted from 1780 to 1801 in the states, nearly twothirds were for enterprises concerned with transport (inland navigation, turnpikes, toll bridges); another 20 per cent were for banks or insurance companies; 10 per cent were for the provision of local public services (mostly water supply); less than 4 per cent were for general business corporations.

Id. at 17 .

35 BERLE \& MEANS, supra note 24, at 122-23.

36 Millon, supra note 4, at 210 (identifying banking, transportation, and insurance companies as among those having special provisions "designed to protect the public from abusive practices").

37 See, e.g., N.Y. BUS. CORP. LAW $§ 57$ (Consol. 1909) (holding shareholders liable for debts due to corporate "laborers, servants or employees"); MASS. GEN. LAWS. ch. 106, § 61 (1882) (same).

38 Millon, supra note 4, at 213.

$39 \quad I d$. at 212. 


\section{Public Interest versus Private Concern}

The third distinction, which "has received a good deal less attention" examines whether the activities of corporations "justify a body of corporate law that is deliberately responsive to public interest concerns, ${ }^{, 41}$ or whether the law should treat corporations as "governing little more than the private relations between the shareholders of the corporation and management."

Proponents of the nexus of contracts theory address each of the above dimensions. ${ }^{43}$ As noted above, contractarians characterize the corporation as the result of a combination of individual activities, and not as an entity in and of itself. ${ }^{44}$ They see the corporation as a creation of the choices of private actors, only tied to the state by formalities, ${ }^{45}$ many of which are ultimately unnecessary. ${ }^{46}$ Finally, they embrace Adam Smith's concept of the invisible hand of the market, ${ }^{47}$ contending that the individuals engaged in the buying and selling of goods and services in a free market will naturally act in a way that promotes the best interests of society. Under such a view, the state need not interfere in the conduct of corporations in order to promote the general welfare. Furthermore, they contend that the state need not take special steps to protect corporate shareholders, for actors who choose to use the corporate form will tend to negotiate terms in this contract that are in the best interests of all constituents of the corporation. The role of the law, once again, should therefore be no more than the same enforcement of contracts as may occur in any other setting. ${ }^{48}$

\section{B. A Brief History of Ideas of the Corporation}

Because theories of the corporation are in part a function of their place in history, it is necessary to review the times and events which accompanied the ideological shifts that led to the current theories. The corporation in America began as a remnant of the English system, where market turbulence caused by over-speculation in stock companies had led to the creation of the doctrine whereby the corporate charter could only be granted by the

40 Id. at 201. It is this distinction, however, which provides the basis for the debate between Adolf A. Berle, Jr. and E. Merrick Dodd, Jr., discussed supra note 19.

41 Id. at 201.

42 Id.

43 See generally EASTERBROOK \& FISCHEL, supra note 1.

44 Jensen \& Meckling, supra note 10, at 9.

45 See, e.g., Ribstein, Limited Liability, supra note 1, at 86-87 (discussing different theories justifying the existence of the filing requirement).

$46 I d$. at 86 (asserting that "state creation is an historical relic").

47 ADAM SMITH, supra note 28, at 485.

48 EASTERBROOK \& FisCHEL, supra note 1 , at 8. 
government. ${ }^{49}$ Parliament had "passed legislation that required a Royal charter for companies seeking investment funds from the public," this "statute was imposed on the American colonies in 1741.,"51 The United States Constitution left this question to the states.

The popular conception of the corporation as a separate entity is longstanding. "From the early years of the 19th century, certain legal attributes of incorporation encouraged Americans to conceive of the corporation as an entity existing separately from its shareholders and other participants."53 Chief among these was the fact that the corporation could only be created by an act of the state. ${ }^{54}$ Initially, states required corporate filings to declare a specific purpose to which the corporation would then be limited-building a road between two particular towns, for example. ${ }^{55}$ Legal action could be taken against the directors of a corporation that went beyond its charter by shareholders, by the corporation, or by the state itself. ${ }^{56}$ Because each corporation initially had to be chartered by the legislature of its home state, "public suspicion about favoritism and corruption in the granting of corporate charters led some critics to advocate abolition of incorporation alto-

49 MARKHAM \& HAZEN, supra note 28, at 3- 4.

50 Id. at 4, noting also that "[t]he granting of corporate powers was viewed to [be] a prerogative of the government as early as 1612 . . .." Id. at 4, n.7. See also ADAM SMITH, supra note 28, at 429-431 (describing how corporations were formed primarily for the purpose of running townships).

51 MARKHAM \& HAZEN, supra note 28 , at 4.

52 Id.

53 Millon, supra note 4, at 205-06.

54 Id. at 206.

55 See Wiswall v. The Greenville and Raleigh Plank Road Co., 56 N.C. (3 Jones Eq.) 183 (1857). In that case, a corporation had been set up to build a plank road between the cities referenced in its name, and to charge tolls upon that road. The managers sought to expand into the business of delivering mail, but stockholders easily persuaded the court to block this effort under the doctrine of ultra vires:

[A] corporation has a right to restrain by injunction the corporators from doing any act which is not embraced within the scope and purpose for which the corporate body was created, and which would be a violation of the charter; not only on the ground that such act would operate injuriously upon the rights and interests of the corporators, but on the further ground that a forfeiture of the charter would be thereby incurred.

Id. at 18; see also Cent. R.R. Co. v. Collins, 40 Ga. 582 (1869) (enjoining one railroad corporation from buying a large amount of stock in another on the grounds that prospective purchaser's corporate charter did not grant it the authority to invest corporate funds).

56 See Edward G. Reitler, Austin v. Mich. Chamber of Commerce: Re-Examining Corporate Political Rights Under the First Amendment, 11 U. BRIDGEPORT L. REV. 449, 454-55 (1991); Sandra K. Lueckenhoff, A. Lincoln, A Corporate Attorney and the Illinois Central Railroad, 61 Mo. L. REV. 393, 406 (1996) (stating that "typically based on a serious violation of the charter or a breach of legal procedure, the attorney general brought suit against corporations to obtain a forfeiture of their charter," and remarking that "[t]he state was often successful in quo warranto cases" but that the courts "showed some reluctance to dissolve a corporation when the suit involved a successful business enterprise"); see also HERBERT HOVENKAMP, ENTERPRISE AND AMERICAN LAW 1836-1937, at 46-47 (1991) (contending that quo warranto actions were almost exclusively taken against public utility corporations). 
gether." ${ }^{\text {57 }}$ States instead responded by enacting laws that eliminated the specter of favoritism by "ordaining simple procedures that could be followed by anyone seeking to incorporate., ${ }^{, 58}$ As far back as the 1870 s, some states began allowing the more relaxed standard of incorporation for the purpose of "carrying on any lawful business."

The relaxation of incorporation laws soon took on a more competitive purpose, which was of particular concern to Louis Brandeis, a turn-of-thecentury lawyer who became famous for representing the interests of labor, ${ }^{60}$ and who was ultimately appointed to the United States Supreme Court by his friend and confidant, Woodrow Wilson. ${ }^{61}$ As Justice Brandeis discusses in his famous dissenting opinion in Louis K Liggett Co v. Lee: ${ }^{62}$

The removal by the leading industrial States of the limitations upon the size and powers of business corporations appears to have been due, not to their conviction that maintenance of the restrictions was undesirable in itself, but to the conviction that it was futile to insist upon them; because local restriction would be circumvented by foreign incorporation. Indeed, local restriction seemed worse than futile. Lesser States, eager for the revenue derived from the traffic in charters, had removed safeguards from their own incorporation laws. ${ }^{63}$

This effort by certain states to attract corporate business through the enactment of the most relaxed set of incorporation laws has been widely charac-

57 Millon, supra note 4, at 208 (citing James W. HuRSt, THE Legitimacy OF THE Business CORPORATION IN THE LAW OF THE UNITED STATES, 1780-1970, at 33-36 (1970) and MARVIN MEYERS, The JaCKSONIAN Persuasion: Politics AND Belief 201 (1957)). But see Sommer, supra note 24, at 36 (contending that fear of monopolization, and later of sheer economic power, were the driving forces behind suspicion of corporations):

Throughout American history, the corporation has been an object of suspicion among the American people. This has derived, historically, from the fact that in its earliest incarnations, the corporation was equated with monopoly, and monopolies posed great opportunities for abuse. Then, as general corporation laws were liberalized and the limitations which had restrained the size of corporate enterprises-limits on capitalization and duration and prohibitions against holding companies-were eliminated, the American public was frightened anew by the specter of enormous concentrations of power crushing them down.

See also Louis D. Brandeis, Other People's Money and How the Bankers Use It, (Augustus M. Kelley Pub. 1971) (1914) [hereinafter BRANDEIS] (raising similar concerns about both monopolistic concentration in the banking industry, and the overwhelming economic power vested in corporations by virtue of the funds under their control).

58 Millon, supra note 4, at 208.

59 Id. at 208. Millon identifies laws to this effect that were enacted in Massachusetts in 1874, New York in 1875, and Maine in 1876. Id. at 208 n.32.

60 Norman Hapgood, Preface to BRANDEIS, supra note 57, at vii, xii.

61 Norman Hapgood, Foreword to BRANDEIS at xix, xxxii.

62288 U.S. 517 (1933)

$63 \quad$ Id. at 557. 
terized as a race to the bottom. ${ }^{64}$ The success of those states prompted fellow states to follow their example, as Brandeis explains in his Liggett dissent:

Companies were early formed to provide charters for corporations in states where the cost was lowest and the laws least restrictive. The states joined in advertising their wares. The race was one not of diligence but of laxity. Incorporation under such laws was possible; and the great industrial States yielded in order not to lose wholly the prospect of the revenue and the control incident to domestic incorporation. ${ }^{65}$

New York and New Jersey were at the forefront of the states that competed to make their laws the most favorable to potential incorporators - a battle in which New Jersey prevailed. ${ }^{66}$ As Brandeis remarks, "[b]y specifically providing that corporations might be formed in New Jersey to do all their business elsewhere, the state made its policy unmistakably clear." ${ }^{, 67}$ In 1910, the United States Supreme Court further spurred the selective incorporation movement by rejecting arguments raised in a series of cases that corporations could not operate outside the boundaries of their states of incorporation. ${ }^{68}$

64 See generally Mark J. Roe, Delaware's Competition, 117 HARV. L. REv. 588, 594 (2003); see also Donald E. Schwartz, Federalism and Corporate Governance, 45 OHIO ST. L.J. 545, 586 (1984) (suggesting that a federal corporate law could prevent this phenomenon). In this era of globalization, this concept is no longer restricted to competition between states within the United States. See Clark D. Stith, Note, Federalism and Company Law: A "Race to the Bottom" in the European Community, 79 GEO. L.J. 1581 (1991) (contending that the removal of political barriers between member nations in the European Community is likely to lead to a similar 'race to the bottom' between those nations, which will relax their national laws in an effort to attract firms from one another). But see EASTERBROOK \& FISCHEL, supra note 1, at 214-15 (arguing that this phenomenon could better be characterized as a "race to the top" because investors benefit from share price increases that tend to follow firms relocating to more corporate-friendly environs).

65288 U.S. at $558-60$

66 Id. at 561-63.

$67 I d$. at 562-63. During the governorship of Woodrow Wilson, New Jersey 'reformed' its incorporation laws, leaving the field open for Delaware to become the state most conducive to incorporation; the authors illustrate the importance of this shift, noting that to this day, Delaware "is the place of incorporation of more than 50 percent of publicly traded corporations," and that "it is the stated policy of the state to stand ready to change its laws to meet the requirements of its corporations chartered there." MARKHAM \& HAZEN, supra note 28, at 10. See also William L. Cary, Federalism and Corporate Law: Reflections Upon Delaware, 83 YALE L.J. 663, 705 (1974) (describing Delaware's success in the "race for the bottom").

68 Southern Ry. v. Greene, 216 U.S. 400, 416-17 (1910) (finding that an attempt by the state of Alabama to assess a tax on a foreign corporation that owned property in Alabama violated the Equal Protection clause); Ludwig v. Western Union Tel. Co., 216 U.S. 146, 164 (1910) (holding unconstitutional a state statute that charged foreign corporations filing fees based on the value of their capital stock); Western Union Tel. Co. v. Kansas, 216 U.S. 1, 18 (1910) (same); Pullman Co. v. Kansas, 216 U.S. 56 (1910) (same). 
The relaxation of the strictures on the formation of corporations naturally increased both their popularity and the size of their operations. States not only eliminated the requirement of a state-granted charter but also removed limits on the size, scope, and duration of the corporation. In his Liggett opinion, Brandeis lamented the rise of giant corporate entities:

The typical business corporation of the last century, owned by a small group of individuals, managed by their owners, and limited in size by their personal wealth, is being supplanted by huge concerns in which the lives of tens or hundreds of thousands of employees and the property of tens or hundreds of thousands of investors are subjected, through the corporate mechanism, to the control of a few men. ${ }^{69}$

But it was not the size of these businesses alone that disconcerted Brandeis. He also raised concerns about the way that these changes affected the operations of these companies:

Ownership has been separated from control; and this separation has removed many of the checks which formerly operated to curb the misuse of wealth and power. And, as ownership of the shares is becoming continually more dispersed, the power which formerly accompanied ownership is becoming increasingly concentrated in the hands of a few. ${ }^{70}$

Brandeis was hardly the only person making such observations. In the 1930's, Adolf Berle and Gardiner Means developed an influential new conception of the public corporation, asserting that separation of ownership from control had become the norm, ${ }^{71}$ and that control had evolved into professional management by persons more interested in their own entrenchment than in advancing the interests of shareholders. Their solution was to "view management's role as that of trustee for the shareholders,", as asserting that "[t]he law holds the management to certain standards of conduct. This is the legal link between ownership and management: ${ }^{73}$

The three main rules of conduct which the law has developed are: (1) a decent amount of attention to 'business'; (2) fidelity to the interests of the corporation; (3) at least reasonable business prudence ... . The law sums up the three rules above mentioned by saying that the manage-

288 U.S. at 565.

Id.

71 Berle \& Means, supra note 35. See also Peter A. Gourevitch, Book Review, The Politics of Corporate Governance Regulation by Mark Roe, 112 YALE L.J. 1829, 1837 (2003) (discussing Roe's interpretation of the work of Berle and Means).

72 Millon, supra note 4, at 221.

73 BERLE \& MEANS, supra note 24, at 220. 
ment stands in a "fiduciary" capacity towards the corporation. Since the corporation is a distinct legal identity, separate and apart from stockholders, it may become necessary to determine whether a director can be honest and faithful with regard to the whole corporation at the same time that he is taking a hostile position towards an individual shareholder. ${ }^{74}$

Berle and Means see the solution in a view taken by some courts at the time:

A minority of courts in the United States adopt the view that the director may not use his position to advantage himself against the interests of any of his shareholders; if he proposes to deal with them he must disclose what he knows, so that the stockholder is at least as able to deal intelligently as is the director himself.

The concept that the managers of the corporation held the investment of the shareholders in trust, and therefore bore the responsibilities of trustees, was therefore not entirely new to the courts. Indeed, this thinking was exemplified in the Michigan Supreme Court's 1919 decision in Dodge v. Ford Motor $C o .{ }^{76}$ In that case, the court ruled that Henry Ford could not lower prices and expand production for the express purpose of bettering society; Ford had a legal duty to run his business "primarily for the profit of the stockholders."

\section{The Jurisprudence of Fiduciary Duties}

\section{The Development of Corporate Fiduciary Duties}

The Restatement (Second) of Trusts defines the fiduciary relationship as one which "exists between two persons when one of them is under a duty to act for or to give advice for the benefit of another upon matters within the scope of the relation." ${ }^{, 78}$ One commonly cited prerequisite to the fiduciary relationship is dependency of one party upon another: "fiduciary duty

74 Id. at 220, 221-22.

$75 \quad$ Id. at 225.

76170 N.W. 668 (Mich. 1919).

77 Id. at 684.

78 Restatement (SECOND) OF TRUSTS § 2 (1959). But see John H. Langbein, The Contractarian Basis of the Law of Trusts, 105 YALE L.J. 625, 629 (1995):

[D]espite decades of pulpit-thumping rhetoric about the sanctity of fiduciary obligations, fiduciary duties in trust law are unambiguously contractarian. The rules of trust fiduciary law mean to capture the likely understanding of the parties to the trust deal, which is why both the duty of loyalty and the duty of prudence yield to the more particularized intentions that the parties may choose to express or imply in their trust deal. 
obligates the stronger party precisely because of the relative weakness of the other party." ing existed in Anglo-American jurisprudence for over a quartermillennium. ${ }^{80}$ Nevertheless, it bears noting that "the exact contours of the concept have remained elusive" ${ }^{\natural 1}$ and that "the historical development of the law of fiduciary obligation is crucial to an understanding of its elusiveness." 82

Fiduciary duties are a descendant of the equitable principles underpinning the law of trusts. " $[\mathrm{C}]$ ases from the late 18th century were based on the broad general principle 'that if a confidence is reposed, and that confidence is abused, a court of equity shall give relief.","84

Equity granted relief - and common law courts did not-in numerous situations involving one person's abuse of confidence reposed in him by another. As Equity evolved, concrete rules in many instances supplanted the chancellors' exercise of discretion based on broad principles; established usages for terms like "trust" and "confidence" replaced an earlier and imprecise vocabulary.

While trusts came to have a very specific meaning, there was no term to describe other relationships in which such confidences were reposed. The word 'fiduciary' came to apply to "situations falling short of 'trusts' but in which one person was nonetheless obliged to act like a trustee." ${ }^{, 86}$ The assignment of fiduciary duties to corporate officers stems from agency principles that were applied in partnerships, ${ }^{87}$ although "fiduciary duties among members of business entities today exist as a result of both statutory and common law development." ${ }^{, 88}$ The imposition of fiduciary duties is intended to exact a particularly high standard of conduct on the person who is re-

79 Claire Moore Dickerson, Is It Appropriate to Appropriate Corporate Concepts: Fiduciary Duties and the Revised Uniform Partnership Act, 64 U. CoLO. L. Rev. 111, 116 (1993) [hereinafter Dickerson, Fiduciary Duties].

80 Shaffer, supra note 2, at 482.

81 Id.

82 Deborah A. DeMott, Beyond Metaphor: An Analysis of Fiduciary Obligation, 1988 DuKE L.J. 879,880 (1988).

83 Dickerson, Fiduciary Duties, supra note 79, at 115-16.

84 Shaffer, supra note 2, at 483 (citing Leonard Sedgwick Sealy, Fiduciary Relationships, 1962 CAMBRIDGE L.J. 69 (1962)), who was in turn quoting Lord Thurlow in Gartside v. Isherwood, 28 Eng. Rep. 1297, 1298 (1783), citing Filmer v. Gott, 2 Eng. Rep. 156 (1774).

85 DeMott, supra note 82, at 880.

86 Id.; see also Shaffer, supra note 2, at 483.

87 Tammy Savidge Moore, Note, The Policy of Opting-Out of Fiduciary Duties in a Limited Liability Company: Mc Connell v. Hunt Sports Enterprises, 42 S. TEX. L. REv. 183, 187-88 (2000).

88 Id. at 187. 
quired to observe them. As Judge Cardozo famously wrote in Meinhard v. Salmon: ${ }^{89}$

Many forms of conduct permissible in a workaday world for those acting at arm's length, are forbidden to those bound by fiduciary ties. A trustee is held to something stricter than the morals of the market place. Not honesty alone, but the punctilio of an honor the most sensitive, is then the standard of behavior. ${ }^{90}$

Assessing fiduciary duties to managers of a corporation is not so obvious a direction that the business world would otherwise grind to a halt, but neither is it any great leap away from logic:

Not surprisingly, the corporate form of business organization proved to be fertile ground for application and development of fiduciary principles. A corporation's directors occupy a trustee-like position: unlike trustees, directors do not themselves have legal ownership interests in transferable property beneficially owned by others, but, like trustees, directors are entrusted with powers to use in the interest of others. Invested by corporation statutes with discretionary authority to manage or supervise the management of the corporation's business, directors are bound by fiduciary principles. ${ }^{91}$

Cases like Dodge v. Ford Motor Co., 170 N.W. 668 (Mich. 1919), lay the foundation for the development of this judicial regime of corporate fiduciary duties. The concentration of corporations in Delaware, with its specialized court of equity, promoted the development of this regime:

In the corporate context in the United States, the continued evolution of fiduciary norms was shaped significantly by the institutional fact that the most prominent corporate law court-Delaware's Chancery Court - was (and still is) a separate court of equity, operating with a self-consciously equitable style. ${ }^{92}$

\section{The Nature of Corporate Fiduciary Duties}

In corporate jurisprudence, fiduciary duties have developed into familiar categories, the most commonly assessed being the duty of care and the

\footnotetext{
89164 N.E. 545 (1928). This case has become shorthand for the proposition that parties to certain business relationships_-'coadventurers' in this case, "owe to one another . . . the duty of the finest loyalty . . . . Not honesty alone, but the punctilio of an honor the most sensitive . . . " Id. at 546. Of some tangential interest is the fact that a search of both Westlaw and Lexis turns up no earlier case containing the word 'punctilio.'

$90 \quad I d$. at 546.

91 DeMott, supra note 82, at 880-81.

92 Id. at 881.
} 
duty of loyalty. ${ }^{93}$ The duty of care requires that corporate managers inform themselves of all material facts before undertaking a decision on behalf of the corporation. This duty is mitigated by a number of factors, including the right of managers to rely on the reports of experts rather than investigating every pertinent fact themselves. Managers can also avail themselves of the business judgment rule, a standard applied by courts under which managers will be held harmless for the informed business decisions that they make, even if the decisions turn out poorly for the corporation. ${ }^{94}$

In the case of Smith v. Van Gorkom, ${ }^{95}$ however, the Supreme Court of Delaware found that the managers of a company who sold the company for a profit were nonetheless liable for violating the duty of care because they had not sought a proper valuation of the company before they voted. ${ }^{96}$ Even though the shareholders had endorsed the deal, which would normally be sufficient to alleviate the managers from responsibility for wrongdoing, the court found that the managers in this case had failed to inform the shareholders of their failure to seek a valuation of the company. ${ }^{97}$ Therefore, the court would not release the managers from liability based on the vote of the shareholders. ${ }^{98}$ The Van Gorkom decision had an immediate and profound impact. Following this decision, Delaware "enacted legislation that allowed corporations to remove directors from the duty of care," other states followed suit. ${ }^{100}$ Once this legislation was enacted, the option was followed up by "some ninety percent of Delaware corporations."

93 Moore, supra note 87, at 188.

94 EASTERBROOK \& FiSCHEL, supra note 1, at 93.

95488 A.2d 858 (Del. 1985).

96 Id. at 893.

97 Id.

98 Id.

99 MARKHAM \& HAZEN, supra note 28, at 250.

100 See Thompson, supra note 7, at 406 n.165 ("The only states that do not permit some waiver are: Arkansas, Connecticut, Florida, Illinois, Missouri, Nevada, North Dakota, South Carolina, Vermont, and West Virginia."); accord MARKham \& HAZEN, supra note 28, at 250. See also PAT K. CheW, DIRECTORS' \& OFFICERS' LIABILITY 365-370 (2001) (discussing variations among the states in waiver provisions). Chew identifies the following variations:

Variations from the Delaware statute include:

- allowing officers as well as directors to be covered by these provisions, NEV. REv. STAT. ANN. § 78.037(1) (Michie 2001); N.J. STAT. ANN. § 14A:2-7(3) (West 1989);

- varying the exceptions to include such acts as "reckless disregard for the director's duty . . . in circumstances in which the director was aware, or should have been aware, . . o of a risk of serious injury," or acts constituting "an unexcused pattern of inattention that amounts to an abdication of the director's duty", CAL. CORP. CODE $\S 204(a)(10)(A)$ (West 1987); N.Y. Bus. CORP. LAW $\S$ 402(b) (McKinney 1998);

- providing that provisions are applicable only to actions brought by the corporation or on behalf of the corporation (shareholder derivative suits), CAL. CORP. CODE $§ 204(\mathrm{a})(10)(\mathrm{A})$ (West 1987) or by the shareholders, N.Y. Bus. CORP. LAW $\S 402$ (b) (McKinney 1998); 
No such blanket waiver has been made available for the duty of loyalty, which requires that managers "refrain from competing with the corporation and ... refrain from appropriating corporate opportunities." ${ }^{, 102}$ This duty is often raised when a manager simultaneously serves on the board of directors of multiple corporations which do business with one another. ${ }^{103}$ The business judgment rule is not applied where a breach of the duty of loyalty is alleged-for example, where a manager takes a potential corporate opportunity for his own use, the manager cannot then claim that there was no violation because the opportunity would have been beyond the means of the corporation. ${ }^{104}$ The manager in such a scenario may only take advantage of such an opportunity if the corporation's board of directors makes an informed rejection of the opportunity. Even more absolute is the prohibition against the manager engaging in competition against his own corporation. ${ }^{105}$ While the duty of loyalty can be overcome "by a showing of disclosure and consent," ${ }^{106}$ manifested by a vote of approval by disinter-

- imposing a maximum dollar amount for which directors are liable, VA. CODE ANN. § 13.1692.1(A) (Michie 1988); and

- automatically limiting directors' liability unless the corporation elects otherwise ("opt-out" provisions), OHIO REv. CODE ANN. § 1701.59(D) (West 1999) in contrast to Delaware's requirement that corporations affirmatively adopt charter provisions limiting directors' liability ("opt-in" provisions), Del. Code ANN. tit. 8, § 102(b)(7) (1991 \& Supp. 1994).

Id. at 370 .

101 MARKHAM \& HAZEN, supra note 28, at 250.

102 Moore, supra note 85, at 189.

103 See, e.g., Globe Woolen Co. v. Utica Gas \& Elec. Co., 121 N.E. 378 (N.Y. 1918) (Cardozo, J.) (holding that a party who simultaneously served as the director of two corporations breached his fiduciary duty to one corporation by failing to warn that corporation's board of directors of his plan to exploit their contract with his other corporation). Note that BRANDEIS, supra note 57, at 51-68, would have severely restricted managers from holding multiple directorates, contending:

The practice of interlocking directorates is the root of many evils. It offends laws human and divine. Applied to rival corporations, it tends to the suppression of competition and to violation of the Sherman law. Applied to corporations which deal with each other, it tends to disloyalty and to violation of the fundamental law that no man can serve two masters.

Id. at 51 .

104 See, e.g., Irving Trust Co. v. Deutsch, 73 F.2d 121 (2d Cir. 1934) (holding that directors of an insolvent corporation could not take for themselves an opportunity within the corporation's line of business, despite the contention of said directors that the corporation was financially incapable of taking on the opportunity).

105 This prohibition is traditionally encompassed within the duty of loyalty. See Barbara Ann Banoff, Company Governance Under Florida's Limited Liability Company Act, 30 FLA. ST. U. L. REV. 53, 62 (2002):

[T]he duty of loyalty . . . is divided into three parts: (1) the duty to account for property, profits, or benefits derived from the partnership's business or the use of partnership property, which includes partnership opportunities; (2) the duty not to deal with the partnership as an adversary or on behalf of adverse interests; and (3) the duty not to compete with the partnership.

106 Dickerson, Fiduciary Duties, supra note 79, at 116-17. 
ested members of the Board of Directors, this process is both cumbersome and applicable only on a case-by-case basis. ${ }^{107}$

\section{Development of the Nexus of Contracts Theory of Corporations}

Contractarians would turn corporate fiduciary duties on their head, and would either require parties dealing with the corporation (including shareholders) to contract with the corporation for such duties to be mandated; ${ }^{108}$ or would at least allow such parties to waive all such duties in their dealings. ${ }^{109}$ Of course, both the limited liability company and the nexus of contracts theory are still very young developments when taken in the context of the long history of business organizations. ${ }^{110}$ It was not until 1976 that Michael Jensen and William Meckling first expressed their theory that the corporation could be conceived as a nexus of contracts. ${ }^{111}$ Jensen and Meckling's work was, in turn, based on a 1937 article authored by Ronald Coase, ${ }^{112}$ for which Coase would eventually win the Nobel Prize. ${ }^{113}$ The ideas that underpin Coase's thesis and also provide the underlying foundation for the nexus of contracts theory can be traced back much further still, to Adam Smith's conception that the self-interest of market participants would have the unintended effect of regulating the market to the ultimate

107 See id., stating:

Fiduciary duty, once imposed, may be removed . . . . If a beneficiary knows all relevant facts about a fiduciary's proposed act and consents to it, the fiduciary has not breached the duty of loyalty. Similarly, if the beneficiary asks the fiduciary to work toward a particular result, but the fiduciary states that time pressures will compromise the level of care, and the beneficiary nevertheless urges the fiduciary to act, that fiduciary will not be liable for a breach of the duty of care if the fiduciary's failure is within the scope of the disclosure. For a fiduciary to avoid the burden of a duty by disclosing to and obtaining consent from the beneficiary, the disclosure must be on a case-by-case basis; the fiduciary cannot seek a blanket approval of all subsequent acts. A mandatory core of obligation, consequently, precludes the beneficiary's prospective waiver of the fiduciary's duties of loyalty and care. Moreover, even the case-by-case waiver must be obtained in good faith . . . the traditional standard of good faith for these purposes appears to be higher than the standard applied in arm's length commercial transactions.

108 EASTERBROOK \& FISCHEL, supra note 1, at 12-22.

109 Id.

110 See generally MARKHAM \& HAZEN, supra note 28, at 1-4, noting that variations of the corporate form can be traced back to the Roman Empire, and that England's American colonies were originally developed by the predecessor to the modern American corporation, the joint-stock company.

111 Melvin A. Eisenberg, The Conception That the Corporation Is a Nexus of Contracts and the Dual Nature of the Firm, 24 J. CORP. L. 819 (1999) [hereinafter Eisenberg, Dual Nature]. In support of this proposition, Eisenberg cites Jensen \& Meckling, supra note 10.

112 Ronald H. Coase, The Nature of the Firm, 4 ECONOMICA 386, 387-89 (1937), reprinted in Ronald H. CoAse, The FIRM, The MARKeT, AND THE LAW 33 (1988).

113 Id.; see also Stephen M. Bainbridge, The Board of Directors as Nexus of Contracts, 88 IowA L. REV. 1, 9 (2002) [hereinafter Bainbridge, Board of Directors] (stating that "[t]his model's origins fairly can be traced to Nobel Prize laureate Ronald Coase's justly famous article, The Nature of the Firm"). 
benefit of all parties. ${ }^{114}$ Among Smith's most famous observations was the following:

As every individual, therefore, endeavors as much as he can both to employ his capital in the support of domestic industry, and so to direct that industry that its produce may be of the greatest value, every individual necessarily labours to render the annual revenue of the society as great as he can. He generally, indeed, neither intends to promote the public interest, nor knows how much he is promoting it. By preferring the support of domestic to that of foreign industry, he intends only his own security; and by directing that industry in such a manner as its produce may be of the greatest value, he intends only his own gain, and he is in this, as in many other cases, led by an invisible hand to promote an end which was no part of his intention. Nor is it always the worse for the society that it was no part of it. By pursuing his own interest he frequently promotes that of the society more effectually than when he really intends to promote it. ${ }^{115}$

Smith was suggesting that, left to its own devices, the market would regulate itself-and in so doing, would optimize the distribution of goods and services to those who desired them. Coase, assuming that this was the case, asserted that "[i]f rights to perform certain actions can be bought and sold, they will tend to be acquired by those for whom they are most valuable either for production or enjoyment." ${ }^{, 116}$ In such a system, Coase wondered, why do firms exist at all? ${ }^{117}$ He reasoned that if there were no transaction costs, then there would be no reason for individuals to engage in business by any means other than by each individual immediately purchasing whatever goods or contracting out every service they required from another individual. Coase also argued that in a world without transaction costs, the remaining costs and benefits realized by parties to a market regulated by laws would be unchanged if those laws were repealed; only the mechanisms by which the costs were extracted and benefits conferred would change. ${ }^{118}$ Coase notes with apparent pride, however, that a later commentator on his work had stated that "[t]he world of zero transaction cost turns out to be as strange as the physical world would be without friction."

\footnotetext{
114 See generally ADAM SMITH, supra note 28.

115 Id. at 484-85.

116 COASE, supra note 112, at 12.

117 Id. at 5

$118 \mathrm{Id}$. at $37-38$.

119 Id. at 14.
} 
But transaction costs do exist, and they place a heavy burden on business. ${ }^{120}$ Coase affirms:

In order to carry out a market transaction it is necessary to discover who it is that one wishes to deal with, to inform people that one wishes to deal and on what terms, to conduct negotiations leading up to a bargain, to draw up the contract, to undertake the inspection needed to make sure that the terms of the contract are being observed, and so on. ${ }^{121}$

Coase concludes that the firm is simply the most efficient means of reducing these transaction costs. ${ }^{122}$ In the conception of the firm that Coase derives from this chain of thought, the firm is really nothing more than a collection of shortcuts to avoid transaction costs, a system that guarantees an automatic repeat customer for each of the transactions that would otherwise require the parties involved to search out market information and make new contracts on a continual basis. ${ }^{123}$ This theory captures both the basis for the existence of the firm, and the logical limits to which such cost avoidance can be carried:

[A]lthough production could be carried out in a completely decentralized way by means of contracts between individuals, the fact that it costs something to enter into these transactions means that firms will emerge to organize what would otherwise be market transactions whenever their costs were less than the costs of carrying out the transactions through the market. The limit to the size of the firm is set where its costs of organizing a transaction become equal to the cost of carrying it out through the market. This determines what the firm buys, produces and sells. ${ }^{124}$

This determination also points to an understanding of the regulations that underpin the existence of firms. Coase suggests that these are not solely predicated on the enforcement of competition, but also on the desire to make trade more efficient for the organizers of the firm. He states that economists such as Adam Smith, "ignore or . . . fail to emphasize an alternative explanation for these regulations: that they exist in order to reduce transaction costs and therefore to increase the volume of trade., ${ }^{, 25}$

\footnotetext{
120 At least one commentator has observed, however that "[w]hile economists see transaction costs as a deadweight loss, lawyers and accountants see them as a livelihood." Banoff, supra note 105, at 80 n.115.

121 COASE, supra note 112, at 6.

122 Id. at 38-39.

123 Id.

124 Id. at 7.

125 Id. at 9. Coase follows this with a lengthy quote from Adam Smith wherein the latter suggests that every dealer in goods has an interest in widening the market and reducing competition, but that the
} 
Professor John C. Coffee, Jr., would later popularize the term "contractarians" as the designation for proponents of this theory in a 1989 publication. ${ }^{126}$ Naturally, contractarians and anticontractarians alike have engaged in a seemingly endless variety of disputes regarding the merits of this position. ${ }^{127}$ Even among the contractarians, different explanations are put forth as to how exactly the firm functions as a nexus of contracts. ${ }^{128}$ A number of commentators have specifically taken issue with the phrase, nexus of contracts, and the implication that corporate dealings should therefore be examined only through the lens of the law of contracts. ${ }^{129}$

The nexus of contracts theory follows the lead that Coase established and asserts the position that " $\mathrm{t}]$ he private corporation or firm is simply one form of legal fiction which serves as a nexus for contracting relationships and which is also characterized by the existence of divisible residual claims on the assets and cash flows of the organization which can generally be sold without permission of the other contracting individuals." ${ }^{, 130}$ Followers of this theory have proposed "that all duties in a corporation can be contracted for or away and that the duties set forth in statutory and common law are only part of an 'off the rack' model." ${ }^{131}$ Building on a tradition that reaches back to Adam Smith's Wealth of Nations, ${ }^{132}$ more recent commentators within this school have suggested that, if left to its own devices, the corpo-

latter goal is harmful to the public. Coase reads Smith as arguing that regulations should be tailored so as to avoid narrowing competition. Id.

126 See supra note 8.

127 Stephen Bainbridge claims that, "contractarians and non-contractarians no longer have much of interest to say to one another-we pass like two ships in the night with an occasional exchange of broadsides." Bainbridge, Board of Directors, supra note 113, at 7.

$128 I d$. (arguing that the board of directors of a corporation is itself the nexus of contracts).

129 See, e.g., Jean Braucher, Contract Versus Contractarianism: The Regulatory Role of Contract Law, 47 WASH. \& LEE L. REV. 697 (1990). Braucher notes that even where exchanges fall squarely within the purview of contract law "[t]he law prohibits or makes unenforceable certain harsh terms and contracts because of doubt that they can be validly entered into; the suspicion is that only knowledge, power and judgment problems (often combined with lack of wealth) could produce them." Id. at 717. It has further been noted that the "the term contract often carries unwanted legal meanings," and therefore "can deter rather than promote an understanding of complex legal organization." Oliver E. Williamson, The Firm as a Nexus of Treaties: An Introduction, in THE FIRM AS A NEXUS OF TREATIES (Masahiko Aoki et al. eds., 1990). Some authors have therefore suggested that a more appropriate term would be a nexus of treaties, See generally THE FIRM AS A NeXUS OF TREATIES (Masahiko Aoki et al, eds. 1990). This has yet to prove a popular alternative. Others have attempted to offer a definition of contracts specific to this theory; see, e.g., Eisenberg, Dual Nature, supra note 86, at 822 (contending that "the conception means that the corporation is a nexus of reciprocal arrangements").

130 Jensen \& Meckling, supra note 10, at 9. See also MARKHAM \& HAZEN, supra note 28, at 14.

131 Cynthia S. Grandfield, The Reasonable Expectations of Minority Shareholders in Closely Held Corporations: The Morality of Small Business, 14 DePAul Bus. L.J. 381, 396 (2002), (citing Melvin A. Eisenberg, Contractual Freedom in Corporate Law: The Structure of Corporation Law, 89 CoLUM. L. REV. 1461 (1989) [hereinafter Eisenberg, Contractual Freedom]).

132 EASTERBROOK \& FisCHEL, supra note 1, at 8; see also Bainbridge, Board of Directors, supra note 113 , at 18 . 
ration will be driven by market forces to adopt by contract with investors the strictures most appropriate to the needs of those investors. This theory challenges the longstanding and well-developed practice of courts with regards to corporate managers, which is to impose upon them fiduciary duties of care and loyalty above and beyond anything that has been put to writing by the parties involved with the transactions of the firm. ${ }^{133}$ Contractarians perceive this venerable line of decisions as a burdensome and unnecessary meddling in the exchanges freely bargained for in the business world. ${ }^{134}$ Rather than impose such duties purely as a matter of principle, contractarians urge that where disputes arise over the behavior of managers and directors, "court[s] should attempt to discover what term rational parties would have agreed upon had they focused on the matter."135

In the words of the Supreme Court of Delaware, "[t]he most fundamental principles of corporate governance are a function of the allocation of power within a corporation between its stockholders and its board of directors." ${ }^{\text {"136 }}$ Easterbrook and Fischel, dedicated contractarians, suggest that most states have left the details of this allocation largely in the hands of the parties involved: "The corporate code in almost every state is an "enabling" statute ... [which] allows managers and investors to write their own tickets, to establish systems of governance without substantive scrutiny from a regulator." ${ }^{137}$ Easterbrook and Fischel cite the application of the business judgment rule as further evidence of a proper policy of judicial noninterference with the corporate form. ${ }^{138}$ They argue that "the dynamics of the market drive [managers] to act as if they had investors' interests at heart, ${ }^{, 139}$ and even invoke the ghost of Adam Smith's invisible hand. ${ }^{140}$

\section{E. Application of the Nexus of Contracts Theory of Corporations by Courts}

The debate ignited by the publication of the nexus of contracts theory has been referred to as "the principal corporate law discussion of the last twenty years."

\footnotetext{
133 Butler, supra note 8, at 11-12.

134 Id. at 53-54.

135 Coffee, supra note 8, at 1622.

136 MM Companies, Inc. v. Liquid Audio, Inc., 813 A.2d 1118, 1126 (Del. 2003).

137 EASTERBROOK \& FisCHEL, supra note 1, at 2.

138 Id. at 3 .

139 Id. at 4

140 Id. (stating "It is almost as if there were an invisible hand."). Compare ADAM SMITH, supra note 28 , at 421 .

141 Lipson, supra note 2, at 1192.
} 
yers in recent years," merous traditional legal scholars." ${ }^{, 143}$ Despite this flurry of discussion, this theory remains confined to academic publications as opposed to court decisions. It has been observed of the contractarians, however, that "their efforts have proved to be unpersuasive in the legislatures and courts." 144 This point appears to remain valid, as courts continue to impose fiduciary duties on corporate managers, and even to expand upon them. ${ }^{145}$ Some commentators contend that under some circumstances, managers should be deemed to owe fiduciary duties to other interested parties, such as creditors ${ }^{146}$ and employees. ${ }^{147}$ It is not surprising that the nexus of contracts concept has never gained ground with courts that would be exceedingly reluctant to remove judge-made devices perceived to protect individuals in their dealings with powerful corporate entities. Naturally, the application of this theory by the courts would vitiate the jurisprudence of corporate fiduciary duties. Such duties are often established in the decisions of courts, as they are rarely

142 Butler \& Ribstein, supra note 8, at 3, citing CoASE, supra note 112; Jensen \& Meckling, supra note 10; Fama \& Jensen, Separation of Ownership and Control, 26 J.L. \& ECON. 301 (1983); Klein, Crawford \& Alchian, Vertical Integration, Appropriable Rents, and the Competitive Contracting Process, 21 J.L. \& ECON. 297 (1978); Manne, Mergers and the Market for Corporate Control, 73 J. POL. ECON. 110 (1965). Butler and Ribstein also count themselves among supporters of this theory; See also EASTERBROOK \& FISCHEL, supra note 1; Bainbridge, Board of Directors, supra note 113.

143 Butler \& Ribstein, supra note 8, at 3-4. See, e.g., Victor Brudney, Corporate Governance: Agency Costs, and the Rhetoric of Contract, 85 Colum, L. Rev. 1403 (1985); Kenneth B. Davis, Judicial Review of Fiduciary Decision-Making: Some Theoretical Perspectives, 80 NW. U. L. REV. 1 (1985); Scott FitzGibbon, Fiduciary Relationships Are Not Contracts, 82 MARQ. L. REv. 303 (1999); Deborah A. DeMott, Fiduciary Obligation Under Intellectual Siege: Contemporary Challenges to the Duty to be Loyal, 30 OsGoode Hall L. J. 471 (1992); Alison Grey Anderson, Conflicts of Interest: Efficiency, Fairness and Corporate Structure, 25 UCLA L. REV. 738 (1978); Tamar Frankel, Fiduciary Duties as Default Rules, 74 OR. L. REV. 1209 (1995); Lawrence E. Mitchell, The Fairness Rights of Corporate Bondholders, 65 N.Y.U. L. REv. 1165 (1993).

144 Millon, supra note 4, at 204.

145 See, e.g., Paramount Communications v. QVC Network Inc., 637 A.2d 34 (Del. 1994) (imposing heightened judicial scrutiny on the use of defensive measures by a corporation's board of directors carried out under the guise of creating a strategic alliance with another company).

146 See, e.g., Shaffer, supra note 2 (arguing that fiduciary duties to creditors should be assessed to corporate managers "within the period (or some portion of the period), after a corporation is in financial distress and thereafter until a corporation returns to solvency or files a bankruptcy petition"), id. at 512; but see Lipson, supra note 2 at 1189 (criticizing "the widely held view that the fiduciary duties that corporate directors ordinarily owe to or for the benefit of shareholders should 'shift' to creditors when the corporation is in financial distress").

147 See, e.g., Marleen A. O'Connor, Restructuring the Corporation's Nexus of Contracts: Recognizing a Fiduciary Duty to Protect Displaced Workers, 69 N.C. L. REV. 1189, 1260 (1991) (arguing that, pursuant to the passage of "stakeholder" statutes permitting corporate directors to consider interests of parties other than shareholders, corporations should be found to owe fiduciary duties to employees when fundamental corporate changes are made); accord Katherine Van Wezel Stone, Employees as Stakeholders Under State Nonshareholder Constituency Statutes, 21 STETSON L. REV. 45 (1991). 
specified in the articles of incorporation of any business, ${ }^{148}$ or by legislative action. $^{149}$

Explicit mention of the nexus of contracts theory is rarely found in judicial decisions. Indeed, Judge Easterbrook of the Seventh Circuit is a leading proponent of the nexus of contracts theory, and he has only used the phrase in a decision once-in Central States, Southeast and Southwest Areas Pension Fund v. Sherwin-Williams Co. ${ }^{150}$ Even in that case, the use of the term was merely dicta, unnecessary to the court's decision to uphold an arbitrator's finding that a parent company had not become a new entity through the sale of a subsidiary. ${ }^{151}$

Another example of a court referring to this theory is to be found in Kidde Industries, Inc. v. United States. ${ }^{152}$ In that case, the Court of Federal Claims examined and quickly dismissed as irrelevant the contention raised by a corporation seeking a tax reduction, based on the theory that it was not the entity, but rather the shareholders who bore the risk of a certain transaction:

[T] hat modern economic theory views a corporation as a nexus of contracts among individual stakeholders and evaluates corporate decisions based on how the individual stakeholders are affected. Consistent with this approach ... [the expert put forward by the defense] argued that corporations do not bear risk but rather individual stakeholders bear risk. Hence, defendant argues, in determining whether risk shifting or risk distributing occurred herein, the court should focus on the individual shareholders . . . and the risk faced by these shareholders is not affected when one subsidiary assumes legal responsibility for the claims against the other subsidiaries. ${ }^{153}$

While conceding that this argument "to the extent it presents a purely economic analysis, is straightforward and makes eminent sense," the court nonetheless concluded that "the tax laws do not view corporate actions from the perspective of the corporate shareholders and do not treat corpora-

\footnotetext{
148 It would be unusual for a corporate charter to give shareholders rights against managers beyond those already required by the laws of the state of incorporation.

149 Much legislation does, however, recognize the existence of fiduciary duties, and many legislatures have acted to modify duties established by the courts of their states. See, e.g., supra notes 74-79 and accompanying text.

15071 F.3d 1338 (7th Cir. 1995) (stating that "[a] corporation is just a nexus of contracts, subject to rearrangement in many ways"). Id. at 1341.

151 Id. at 1343 (stating: "There was, and is, only one 'group': the Sherwin-Williams group. No 'old Sherwin-Williams group' and no 'new Sherwin-Williams group.' Just one group comprising changing assortments of assets and operations").

15240 Fed. Cl. 42 (1997).

$153 I d$. at 55.
} 
tions as fictitious entities that can be ignored." tion was not necessary for the decision rendered, the court clearly rejected the nexus of contracts theory as a basis for assessing the liabilities of a corporation.

Although no court has yet applied the nexus of contracts theory as a reason to oppose the practice of imposing fiduciary duties, this by no means makes this result impossible. Such a change in this area would appear to be highly unlikely in the near future, given the strength of the jurisprudence of fiduciary duties. Courts frequently take decades of prodding to undertake fundamental changes to certain areas of the law. ${ }^{155}$ Instances abound, however, of theories long-argued but little regarded suddenly sweeping across the nation to be established as the new majority approach of the courts, ${ }^{156}$ or enacted as state law. ${ }^{157}$

\section{Id.}

155 Application of the doctrine of implied warranty of the seller of defective products is one example of an area where change occurred slowly, deliberately, and in incremental steps. See, e.g., Greenman v. Yuba Power Products, Inc., 377 P.2d 897 (Cal. 1963) (Traynor, J.) (describing the incremental process by which courts moved away from the requirement of privity of contract in strict liability claims based on the warranty of quality made through advertising by the original manufacturer):

Although . . . strict liability has usually been based on the theory of an express or implied warranty running from the manufacturer to the plaintiff, the abandonment of the requirement of a contract between them, the recognition that the liability is not assumed by agreement but imposed by law, and the refusal to permit the manufacturer to define the scope of its own responsibility for defective products make clear that the liability is not one governed by the law of contract warranties but by the law of strict liability in tort.

Id. at 901 (citations omitted); see also William Lloyd Prosser, The Assault Upon the Citadel, 69 YALE L.J. 1099 (1960) (describing the evolution and growth of the implied warranty doctrine from 1913 to 1960).

156 See, e.g., James W. Bozzomo, Joint Legal Custody: A Parent's Constitutional Right In a Reorganized Family, 31 HOFSTRA L. REV. 547, 549 (2002) (discussing the swift abandonment of the "tender years" doctrine, under which courts had generally awarded custody of young children to the mother):

The tender years philosophy dominated the courts' decision making up until the mid-1970s. Recognizing the constitutional nature of parental rights, the tender years doctrine was struck down by most courts as a violation of the equal protection clause of the Fourteenth Amendment because it discriminated against fathers. After this period, courts abandoned the tender years doctrine for gender-neutral rules and applied a best interests of the child test.

157 See, e.g., supra notes 79-80 and accompanying discussion of the swift spread of state statutes permitting corporations to limit the director's duty of care; see also McIntyre v. Balentine, 833 S.W.2d 52 (Tenn. 1992) (judicially dispensing with contributory negligence and instead adopting comparative fault for the state of Tennessee, but discussing how a majority of states have made this change by statute):

Between 1920 and 1969, a few states began utilizing the principles of comparative fault in all tort litigation. Then, between 1969 and 1984, comparative fault replaced contributory negligence in 37 additional states. In 1991, South Carolina became the 45th state to adopt comparative fault, leaving Alabama, Maryland, North Carolina, Virginia, and Tennessee as the only remaining common law contributory negligence jurisdictions. Eleven states have judicially adopted comparative fault. Thirty-four states have legislatively adopted comparative fault.

Id. at 55-56 (internal citations omitted). 


\section{THE DEVELOPMENT OF THE LIMITED LIABILITY COMPANY}

Throughout most of the history of the United States, business organizers essentially have had to choose between two business forms, the partnership and the corporation. ${ }^{158}$ Each of these presents a specific set of advantages (or, perhaps, avoids a specific set of disadvantages), and each has evolved a number of variations which are important in understanding the development of the LLC. ${ }^{159}$ A historical account of the development of the LLC itself appears far more mundane than its storied antecedents, but the LLC may yet have the most interesting tale to tell.

\section{A. Business Organizations Preceding the LLC}

\section{The Partnership}

The partnership is basically the default business form-if two parties do nothing more than "carry on as co-owners a business for profit," they have nevertheless become partners under the law, "whether or not the persons intend to form a partnership." ${ }^{, 60}$ The partnership is therefore unique

158 Larry E. Ribstein, LLCs: Is the Future Here?: A History and Prognosis, 13-DEC Bus. L. TODAY 11, 12 (2003) [hereinafter, Ribstein, LLCs: Is the Future Here?]; see also Banoff, supra note 105, at 54 (noting that until recently, parties have been limited to the partnership, the corporation, and the rarely-used limited partnership, but noting also that some flexibility was afforded by the availability of foreign incorporation).

159 The LLC, as will be shown, is often described as an effort to capture the benefits of the business forms that preceded it, but because the language used in many LLC statutes copies language used in corporation and partnership statutes, the historical treatment of these other forms often guides courts in dealing with LLCs. See, e.g., Cosgrove v. Bartolotta, 150 F.3d 729 (7th Cir. 1998) (Posner, J) (determining that an LLC should be treated as a limited partnership for determining diversity jurisdiction). Judge Posner writes:

Given the resemblance between an LLC and a limited partnership, and what seems to have crystallized as a principle that members of associations are citizens for diversity purposes unless Congress provides otherwise (as it has with respect to corporations, in 28 U.S.C. $§ 1332$ (c)(1)), we conclude that the citizenship of an LLC for purposes of the diversity jurisdiction is the citizenship of its members.

Id. at 731 (internal citations omitted); see also Koh v. Inno-Pacific Holdings, Ltd., 54 P.3d 1270, 1272 (Wash. App. 2002) (referring to the Uniform Partnership Act and the Revised Uniform Partnership Act to interpret similar provisions in the Uniform Limited Liability Company Act); Kaycee Land and Livestock v. Flahive, 46 P.3d 323 (Wyo. 2002) (holding that "[n]o reason exists in law or equity for treating an LLC differently than a corporation is treated when considering whether to disregard the legal entity"); Cimarron Feeders v. Bolle, 17 P.3d 957, 964 (Kan. App. 2d 2001) (holding that trial court committed reversible error, in part for instructing the jury to apply language regarding fiduciary duties in the state's partnership act to the relationships in a limited liability company).

160 UNIF. P'SHIP ACT 1997 § 202: Formation of Partnership:

(a) Except as otherwise provided in subsection (b), the association of two or more persons to carry on as co-owners a business for profit forms a partnership, whether or not the persons intend to form a partnership. 
among business organizations in that it can be created inadvertently. ${ }^{161}$ Parties opting to create a business of any other form must file the appropriate papers with the state. ${ }^{162}$ The partnership has traditionally afforded the greatest flexibility in the organization of management, as the partners are free to assign management responsibilities to any party within or without the partnership, with no interference from the state. ${ }^{163}$ The only caveats to the operation of this business form are that changes to the conduct of the partnership "must be decided by a majority of the partners provided no other agreement between the partners speaks to the issue." ${ }^{64}$ Partners have a fi-

(b) An association formed under a statute other than this [Act], a predecessor statute, or a comparable statute of another jurisdiction is not a partnership under this [Act].

(c) In determining whether a partnership is formed, the following rules apply:

(1) Joint tenancy, tenancy in common, tenancy by the entireties, joint property, common property, or part ownership does not by itself establish a partnership, even if the co-owners share profits made by the use of the property.

(2) The sharing of gross returns does not by itself establish a partnership, even if the persons sharing them have a joint or common right or interest in property from which the returns are derived.

(3) A person who receives a share of the profits of a business is presumed to be a partner in the business, unless the profits were received in payment:

(i) of a debt by installments or otherwise;

(ii) for services as an independent contractor or of wages or other compensation to an employee;

(iii) of rent;

(iv) of an annuity or other retirement or health benefit to a beneficiary, representative, or designee of a deceased or retired partner;

(v) of interest or other charge on a loan, even if the amount of payment varies with the profits of the business, including a direct or indirect present or future ownership of the collateral, or rights to income, proceeds, or increase in value derived from the collateral; or

(vi) for the sale of the goodwill of a business or other property by installments or otherwise.

161 Numerous cases demonstrate the longstanding pedigree of this principle. See, e.g., Dubos v. Hoover, 6 So. 788 (Fla. 1889) (finding that where persons agreed "to place their money, labor, and skill, or some or all of them, in lawful commerce or business [in this case running a hotel and saloon], with the understanding that there shall be a communion of the profits thereof between them," the parties thereby became partners in that business, and subject to the duties and strictures of that business form). It is for this reason that the partnership remains a necessary area of study in any business organizations course, despite the fact that partnership is in many respects the least attractive business form.

162 See, e.g., Ribstein, Limited Liability, supra note 1 (discussing the theory that the longstanding historical filing requirement for corporations support theories of the state's role in the corporate form, and concluding that "in order to preserve their control of corporate terms states must constrain the parties' ability to obtain limited liability without incorporating or making some other state filing"). Id. at 91; see also MARKHAM \& HAZEN, supra note 28, at 65 (noting that "a limited partnership is formed only by complying with statutory formalities similar to those required for the creation of a corporation").

163 William A. Gregory \& ThOMAS R. HuRst, UninCorporated BusinesS ASSOCIATIONS 371 (2d Edition 2002); (noting that "the corporation being a creature of statute, the parties have less freedom to vary their relationship among themselves or with third parties than in a partnership").

164 Summers v. Dooley, 481 P.2d 318, 321 (1971) (holding that one partner in a garbage collection business could not be required to contribute to the salary of a person unilaterally hired by the other partner); Nat'1 Biscuit Co., Inc. v. Stroud, 106 S.E.2d 692 (N.C. 1959) (holding that one of two partners 
duciary relationship to one another with regards to matters affecting the partnership. The great disadvantages to a partnership are that the ownership interest is non-transferable, and that all partners have unlimited liability for debts arising from both the contracts and torts of the firm. ${ }^{165}$ The partnership, therefore, bears the burdens of unlimited liability and lack of transferability, but avoids complexity, lack of control by the owner, and doubletaxation. $^{166}$

\section{The Limited Partnership (LP)}

A variation of the partnership, the limited partnership (LP), was first created in the state of New York in $1822 .{ }^{167}$ Like other complex business forms, parties seeking to form a limited partnership must file the appropriate papers with the state. ${ }^{168}$ Under this businesses form, general partners remain liable for the obligations of the firm, but limited partners are only

in a grocery business could not unilaterally cease an ongoing business relationship with the partnership's current supplier of bread).

165 See generally Meinhard v. Salmon, 164 N.E. 545 discussed supra note 89 and accompanying text; see also Elizabeth M. McGeever, Hazardous Duty? The Role of the Fiduciary in Noncorporate Structures, 4-APR BUS. L. TODAY 51 (1995) (stating that "[t]he universally accepted norm that partners owe fiduciary duties among themselves and to the partnership stems from the early English system, where all mercantile matters including partnership cases were handled by equity courts."); MARKHAM \& HAZEN, supra note 28, at 20.

166 See Richard M. Lipton, Acquiring or Selling the Privately Held Company, PRAC. LaW INST. JUNE-JULY (2003) (stating that "[t]o avoid double taxation, a business owner may choose an entity which does not risk double taxation, namely, proprietorships, partnerships, limited partnerships, LLCs classified as partnerships, and, generally, S corporations.")

167 Susan Pace Hamill, The Origins Behind the Limited Liability Company, 59 Оніо ST. L.J. 1459, 1502 (1998). Hamill explains this history as follows:

In 1822, New York enacted the first limited partnership statute as an alternative to the business corporation. The New York statute envisioned two classes of partners: the general partners who were fully liable and limited partners who only had their capital contribution at risk. Over the following twenty-year period, most states enacted similar statutes as an attempt to slow the increased use of the business corporation. However, the early limited partnership statutes were seldom used.

Id. at $1502 \mathrm{n} .192$; accord GREGORY \& HURST, supra note 163, at 705; MARKHAM \& HAZEN, supra note 28 , at $16-17,65$.

168 See, e.g. UNIF. LTD. P'SHIP ACT 2001 § 201, stating:

(a) In order for a limited partnership to be formed, a certificate of limited partnership must be delivered to the [Secretary of State] for filing. The certificate must state:

(1) the name of the limited partnership, which must comply with Section 108;

(2) the street and mailing address of the initial designated office and the name and street and mailing address of the initial agent for service of process;

(3) the name and the street and mailing address of each general partner;

(4) whether the limited partnership is a limited liability limited partnership; and

(5) any additional information required by [Article] 11. 
liable for the amount of their investment, ${ }^{169}$ so long as those partners do not take an active role in the management of the firm.

An interesting twist to this model is the fact that the general partner may be a corporation. ${ }^{171}$ In theory and practice, it is possible for a limited partnership to be formed wherein the general partner is a corporation, and some or all of the limited partners are members of the board of directors of that corporation. Those limited partners may then freely participate in the management of the corporation, which is managing the partnership. ${ }^{172}$ In this way, the parties to this business may be able to avoid taxation, unlimited liability, and the separation between ownership and control. As officers in the corporation, however, they will be burdened with the fiduciary duties to other shareholders in the corporation that typical limited partners might

169 GREGORY \& HURST, supra note 163, at 4.

170 See, e.g., Gateway Potato Sales v. G.B. Inv. Co., 822 P.2d 490 (Ariz. Ct. App. 1991) (finding that purported limited partner who exercised control over the activities of the partnership could be held liable as a general partner); see also GREGORY \& HURST, supra note 163, at 4.

171 See, e.g., UNIF. LTD. P'SHIP ACT 2001 § 201, stating:

(8) "General partner" means:

(A) with respect to a limited partnership, a person that:

(i) becomes a general partner under Section 401; or

(ii) was a general partner in a limited partnership when the limited partnership became subject to this [Act] under Section 1206(a) or (b); and

(B) with respect to a foreign limited partnership, a person that has rights, powers, and obligations similar to those of a general partner in a limited partnership.

.

(14) "Person" means an individual, corporation, business trust, estate, trust, partnership, limited liability company, association, joint venture, government; governmental subdivision, agency, or instrumentality; public corporation, or any other legal or commercial entity.

FLA. STAT. ANN. § 620.108(1) (West 1997) stating:

(c) Each general partner that is a legal or commercial entity and not an individual must be organized or otherwise registered with the Department of State as required by law, must maintain an active status, and must not be dissolved, revoked, or withdrawn.

DEL. CODE ANN. tit 6, § 17-101 (1997) stating:

(5) "General partner" means a person who has been admitted to a limited partnership as a general partner in accordance with the partnership agreement and so named in the certificate of limited partnership or similar instrument under which the limited partnership is organized if so required. . .

(14) "Person" means a natural person, partnership (whether general or limited), limited liability company, trust, estate, association, corporation, custodian, nominee or any other individual or entity in its own or any representative capacity, in each case, whether domestic or foreign.

172 See, e.g., FLA. STAT. ANN. \$ 620.129 (West 1997):

(2) A limited partner does not participate in the control of the business within the meaning of subsection (1) solely by doing one or more of the following things:

(a) Being a contractor for or an agent or employee of the limited partnership or of a general partner or being an officer, director, or shareholder of a general partner that is a corporation. 
otherwise be able to avoid. Furthermore, courts may place upon persons holding such a dual role the burden of proving that their activities were solely conducted within the scope of their office in the corporation. ${ }^{173}$ Some courts have rejected this construction outright as an attempt to evade the strictures of the LP form. ${ }^{174}$ At least one recent case suggests, however, that members of the limited partnership itself can contract around the imposition of fiduciary duties. ${ }^{175}$

\section{The Corporation}

Addressing the corporation, Ribstein notes that "[f]irms long have had other ways of obtaining limited liability-most notably, by incorporating," ${ }^{176}$ but goes on to point out the many deficiencies of the corporate form, including increased costs, and having to choose between entity taxation $^{177}$ or accepting the limitations accompanying Subchapter S status. ${ }^{178}$ The corporation is, in many ways, the opposite of the partnership. Formation of a corporation allows parties to avoid unlimited liability for both owners and managers, but also requires them to accept strict limitations on the way the firm can be organized and managed, ${ }^{179}$ and to accept the impo-

173 See, e.g., Gonzalez v. Chalpin, 565 N.E. 2d 1253 (N.Y. 1990) (holding that a limited partner who was also president, sole shareholder and director of the corporate general partner was liable for debts of the partnership where said limited partner failed to prove that he acted as officer of general partner on behalf of partnership, and not individually, in incurring a debt upon the partnership).

174 See, e.g., Delaney v. Fidelity Lease Ltd., 526 S.W. 2 d 543 (Tex. 1975) (holding that "the personal liability, which attaches to a limited partner when 'he takes part in the control and management of the business,' cannot be evaded merely by acting through a corporation"). Id. at 545 .

175 Sonet v. Timber Co., L.P., 722 A.2d 319 (Del. Ch. 1998) (holding that provisions of a limited partnership agreement vesting sole discretion in case of a merger in the general partner absolved said general partner of the fiduciary default rule, which would otherwise have required the general partner to be 'fair and reasonable to the partnership').

176 Larry E. Ribstein, The Emergence of the Limited Liability Company, 51 Bus. LAW. 1, 22 (1995) [hereinafter Ribstein, Emergence]. Professor Ribstein has become perhaps the foremost authority on the nature of the LLC, and has authored or co-authored no fewer than nine law review articles discussing the LLC. Professor Ribstein has also co-authored with Professor Robert R. Keatinge multiple editions of an extensive treatise on the topic, LARRY E. RIBSTEIN \& ROBERT R. KEATINGE, RIBSTEIN AND KEATINGE ON LIMITED LIABILITY COMPANIES (1998).

177 Ribstein, Emergence, supra note 176, at 3 (explaining entity taxation as "taxation on income at the corporate level when it is earned and again at the shareholder level when it is distributed as dividends").

$178 I d$. at 2-3. Ribstein identifies the limitations placed on corporations seeking Subchapter S status as those "prohibiting more than thirty-five shareholders, restricting who may own stock, forbidding an allocation of dividend and liquidation rights that creates more than one 'class' of stock, and requiring shareholders to allocate income, loss, deduction, and credit in direct proportion to their interests in the corporation." These limitations change from time to time, and since the time of Ribstein's writing, the permissible number of shareholders has been raised to 75; see James F. McCrackin, Recent Changes to $S$ Corporation Rules, 8-FEB S.C. LAW 32 (1997).

179 See, e.g., DEL. CODE ANN. tit. 8, § 141 (2000) (requiring the corporation to have its business managed by a board of directors, setting the minimum quorum at $1 / 3$ of the total number of directors, permitting the board of directors to be divided into no more than 3 classes, and placing conditions on the 
sition of fiduciary duties running from officers to owners. ${ }^{180}$ The basic blueprint of a corporation is a business entity where ownership is vested in shares of stock issued by the entity, while management is vested in a board of directors elected by the shareholders.

Some variations of the corporate form are also possible by maintaining the corporation as a closely held firm, or as a Subchapter ' $S$ ' corporation, or both. Courts have adopted a definition of the close corporation as one that is "typified by: (1) a small number of stockholders; (2) no ready market for the corporate stock; and (3) substantial majority stockholder participation in the management, direction and operations of the corporation." ${ }^{, 181}$ As Professor Ribstein observes, "case and statutory law long have allowed closely held firms to adapt the corporate form to their distinct needs by adopting direct member-management, restricting transferability, and giving members a means of exit through buyout or dissolution." ${ }^{182}$ Close corporations are really a category apart from publicly held corporations, as they afford additional benefits and may extract additional burdens in the form of heightened fiduciary duties to minority owners. ${ }^{183}$

A particular set of drawbacks is incumbent upon this business form:

This approach, however, puts the burden on closely held firms to engage in costly and detailed planning. Where planning is imperfect, as it so often is in closely held firms, the standard corporate default rules are ready to strike. Unwary minority members may be frozen into an economically inferior position. The cure for this may be worse than the disease-subjecting the firm to ad hoc judicial remedies that tend to ignore the deals the parties actually have made. ${ }^{184}$

power to remove directors); DEL. CODE ANN. tit. 8, § 211 (2000) (requiring annual meetings of the stockholders and vesting in the court of chancery the power to compel such a meeting if one is not held within thirteen months); DEL. CODE ANN. tit. 8, § 222 (2000) (requiring stockholder meetings be preceeded by written notice containing certain information and within a certain timeframe).

180 See supra note 78-107 and accompanying text for discussion of the fiduciary duties thus imposed.

181 Donahue v. Rodd Electrotype Co., 328 N.E.2d 505, 511 (Mass. 1975). But see F. Hodge O'NeAL \& ROBERT B. THOMPSON, O'NEAL's Close CORPORATIONS: LAW AND PRACTICE § 1.02 (1996) (suggesting that the term "close corporation" should encompass any corporation "whose shares are not generally traded in the securities markets").

182 Ribstein, Emergence, supra note 176, at 2.

183 MARKHAM \& HAZEN, supra note 28, at 358-386. Interestingly, the authors note at the end of this section that " $[\mathrm{t}]$ he fiduciary obligations in Donahue and Meiselman [both cases establishing heightened fiduciary duties owed by majority owners to minority owners in close corporations] are based on analogy to partnership law." Id. at 387; see Donahue, supra note 179; Meiselman v. Meiselman, 307 S.E.2d 551 (N.C. 1983). The authors then ask, "What basis, if any, is there for finding a different standard of conduct applicable to dealings between members in limited liability companies?" MARKHAM \& HAZEN, supra note 28, at 387.

184 Ribstein, Emergence, supra note 176, at 2-3. 
The possibility exists that a minority shareholder in a close corporation may find herself in an untenable position, possessing stock which they cannot sell for lack of a market, but which affords her no control over the business, because of her minority position. The controlling shareholders (or their elected directors) may opt to continually reinvest profits and never pay dividends. Courts have sought to remedy this by creating heightened fiduciary duties for majority shareholders in close corporations-the "cure that may be worse than the disease" to which Ribstein refers above. Furthermore, most states that provide special rules for close corporations require the business to register in this form with the state. ${ }^{185}$

It is important to note that the close corporation and the "Subchapter $S$ " corporation are not identical, although they are related concepts in that both entail legislative efforts to relieve smaller companies of the burdens associated with incorporation. Corporations that fall into one of these categories are certainly likely to overlap with the other. As Ribstein explains:

Congress created the Subchapter S corporation, which permitted partnership-type taxation in the corporate form. Congress hoped this device would satisfy the craving for single-level taxation in the simplest corporations without inviting abuse. But this enforced simplicity makes Subchapter $\mathrm{S}$ a kind of straightjacket, limiting the number and type of members and, most important, confining firms to a single-class capital structure. $^{186}$

Hence we have Subchapter S corporations which avoid double taxation and still manage to avoid unlimited liability, but at the price of staying relatively small and simple; and we have close corporations which have no special

185 See, e.g., DEL. CODE ANN. tit. 8, § 351 (2000):

The certificate of incorporation of a close corporation may provide that the business of the corporation shall be managed by the stockholders of the corporation rather than by a board of directors. So long as this provision continues in effect:

(1) No meeting of stockholders need be called to elect directors;

(2) Unless the context clearly requires otherwise, the stockholders of the corporation shall be deemed to be directors for purposes of applying provisions of this chapter; and

(3) The stockholders of the corporation shall be subject to all liabilities of directors.

Such a provision may be inserted in the certificate of incorporation by amendment if all incorporators and subscribers or all holders of record of all of the outstanding stock, whether or not having voting power, authorize such a provision. An amendment to the certificate of incorporation to delete such a provision shall be adopted by a vote of the holders of a majority of all outstanding stock of the corporation, whether or not otherwise entitled to vote. If the certificate of incorporation contains a provision authorized by this section, the existence of such provision shall be noted conspicuously on the face or back of every stock certificate issued by such corporation.

186 Ribstein, LLCs: Is the Future Here?, supra note 158, at 12. 
taxation status ${ }^{187}$ but which avoid unlimited liability. As Ribstein notes above, may avoid a great deal of corporate complexity by opting to have direct member-management, where this is permitted.

\section{B. The Birth of the LLC}

The first LLC statute, enacted in Wyoming in 1977, enabled parties seeking to participate in business for profit to pursue this desire under an entirely new kind of business organization: the limited liability company (LLC). ${ }^{188}$ Commentators tend to characterize the LLC as "a hybrid of the corporate and partnership forms." "189 The creation of the LLC was an effort to establish a business form that combined the benefits offered by the two most prominent existing business forms of the time. ${ }^{190}$ The Wyoming LLC

187 Close corporations may or may not avoid double taxation, depending on whether they qualify for Subchapter S status. The determination that a business is a 'close' corporation is entirely a matter of state law, but close corporations are more likely to fall within the restrictions placed on Subchapter S corporations.

188 Wyo. STAT. AnN. $\S \S 17-15-101$ to -136 (1977) (titled the "Wyoming Limited Liability Company Act").

189 Ribstein, Emergence, supra note 176, at 2. The purported hybrid nature of the LLC, or at least the desire for such a business form, has inspired some interesting attempts to create a new vocabulary of business organizations. Ribstein, for example, asserts that "we needed a business form that combined the most useful elements of both partnerships and corporations for closely held firms . . the 'partneration." Ribstein, LLCs: Is the Future Here?, supra note 158, at 11. Ribstein further notes that "general partners [in Limited Partnerships] could incorporate, thereby creating what has been called a corpnership." Id. The LLC itself has been labeled a "lamb with mandibles of death." J. William Callison \& Allan W. Vestal, “They've Created a Lamb with Mandibles of Death”: Secrecy, Disclosure, and Fiduciary Duties In Limited Liability Firms, 76 IND. L.J. 271, 279 (2001) [hereinafter Callison \& Vestal]. But the most interesting word used to capture the nature of the LLC must be the one used by Daniel S. Kleinberger, Sorting Through the Soup: How do LLCs, LLPs and LLLPs Fit within the Regulations and Legal Doctrines?, 13-DEC Bus. L. TODAY 15 (2003):

In a children's book published in 1946, Ben Ross Berenberg described an imaginary amalgam called the churkendoose-_part chicken, turkey, duck and goose." In 1977, Wyoming invented a business law churkendoose: the limited liability company-part corporation, part general partnership, part limited partnership. That churkendoose has revolutionized the law of business organizations ....

Kleinberger also addresses the difficulties that some courts have had in properly using the terminology of this new business form:

More than one court has referred to an LLC as "a limited liability corporation" or to LLC members as shareholders, and one case referred to an LLC's members as "limited liability partners." In another case the court had to determine which long-arm statute to apply to an entity described in the key contract as "United Restoration, LLC, A Florida Corporation."

Id.

190 This is, at least, the conventional view of the purpose of the LLC. I argue, however, the subtle but important distinction that "it might be equally appropriate to characterize it as an entity that avoids the disadvantages of all other business forms," because proponents of the modern LLC seek to use this form to avoid burdens that are imposed on all other business forms. See infra notes 281-286 and accompanying text. 
statute provided "limited liability for all members, ${ }^{191}$ partnership features such as dissolution at will ${ }^{192}$ and lack of free transferability, ${ }^{193}$ and members' ability to participate in control ${ }^{194}$ without risking loss of their limited liability.",195

Professor Ribstein characterizes the Wyoming LLC legislation as a "little-noticed development that ultimately led to a new era in business forms." ${ }^{196}$ Such legislation, however, essentially legitimated a business form that was already in use, as "it was not a large leap from the liability afforded by using limited partnerships with thinly-capitalized, single-purpose corporate general partners, allowed by incremental income tax law changes, to protection without the corporate intermediary." far cry from a close corporation that also qualifies for Subchapter S status, wherein either the members have opted to manage the business directly, or where all of the shareholders are on the board of directors, or are entitled to elect a representative to the board of directors. ${ }^{198}$ Indeed, in some states, if such a close corporation were the general partner in a limited partnership, the shareholders of the close corporation could directly manage the close corporation without even having the formality of a board of directors. ${ }^{199}$

191 WYO. STAT. ANN. § 17-15-113 (1977), titled “Liability of members and managers," stating:

Neither the members of a limited liability company nor the managers of a limited liability company managed by a manager or managers are liable under a judgment, decree or order of a court, or in any other manner, for a debt, obligation or liability of the limited liability company.

192 Wyo. STAT. ANN. $\S ~ 17-15-124$ to -126 and -128 (1977), respectively titled "Filing of statement of intent to dissolve"; "Effect of filing of dissolving statement"; "Distribution of assets upon dissolution"; and "Filing of articles of dissolution"; these statutes collectively permit the LLC to dissolve upon the delivery of the appropriate paperwork to the secretary of state. It should be noted, however, that corporations also enjoy the ability to dissolve if this is the desire of the owners.

193 WYO. STAT. ANN. § 17-15-122 (1977), titled "Interest in company; transferability of interest," stating:

$[\mathrm{I}] \mathrm{f}$ all of the other members of the limited liability company other than the member proposing to dispose of his or its interest do not approve of the proposed transfer or assignment by unanimous written consent, the transferee of the member's interest shall have no right to participate in the management of the business and affairs of the limited liability company or to become a member.

194 WYO. STAT. ANN. § 17-15-107(ix) (1977), titled “Articles of organization" and laying out simple procedures by which business organizers are permitted to indicate whether the limited liability company "is to be managed by a manager or managers," or whether "the management of a limited liability company is reserved to the members."

195 Ribstein, LLCs: Is the Future Here?, supra note 158, at 11.

196 Id.

197 J. William Callison, Rationalizing Limited Liability and Veil Piercing, 58 Bus. LAW. 1063, 1064 (2003).

198 Such an arrangement, however, does raise the danger that courts may assess heightened fiduciary duties towards majority shareholders towards minority shareholders. See supra notes 148-152 and accompanying text.

199 See, e.g., N.Y. BuS. CORP. LAW § 620 (McKinney 1963 \& Supp. 1982) (permitting shareholders to vote by unanimous agreement to manage the corporation by directly voting their shares, bypassing the very existence of a board of directors). 
They might thereby be able to avoid both unlimited liability and double taxation. Furthermore, being only limited partners in the partnership themselves, they could arguably claim that they owed no fiduciary duties to any other limited partners who were not also shareholders in the corporate general partner. Of course, accomplishing all of this through a single business form would save participants much time and effort. ${ }^{200}$

Returning to the Wyoming statute, some commentators suggest that the LLC was inspired by business organizations prevalent in other countries. The Prefatory Notes to the Uniform Limited Liability Company Act ("ULLCA") support that contention, asserting that Wyoming arrived at this statute by "[b]orrowing from abroad." "201 Some point to business forms employed in England, France, and Latin America, ${ }^{202}$ while others suggest that the LLC "[a]ppears to be modeled after the German GmbH that was established in 1892 for small German enterprises." ${ }^{203}$ The Florida LLC statute, enacted in $1982,{ }^{204}$ may also have borrowed from abroad, apparently having been crafted with the belief that "similarities between the Florida LLC and the South American limitada would provide a familiar investment vehicle [to South Americans] and attract a deluge of foreign capital into the state." ${ }^{, 25}$ Others commentators have theorized that the development of the LLC was simply the inevitable product of an evolutionary process in business organizations. ${ }^{206}$

Irrespective of its origin, the statute passed in Wyoming was "missing some critical elements such as detailed rules regarding fiduciary duties and the agency powers of members and managers.",207 Thus the LLC "was not truly born . . . until 1988 when it was 'spanked ${ }^{208}$ by Revenue Ruling 88-76

200 See James W. Lovely, Agency Costs, Liquidity, and the Limited Liability Company as an Alternative to the Close Corporation, 21 STETSON L. REV. 377 (1992) (urging the LLC as an alternative to the close corporation precisely because of the reduction in agency costs).

201 UNIF. LTD. Liability Co. ACT, Prefatory Note, at i (2003).

202 Lovely, supra note 200, at 81-83 (asserting that "Although the LLC is a very new organizational form in American law, it has an extensive history in both England and civil law countries" and discussing the history of purported predecessor business forms in England, France, and South America); cf. Terry A. O'Neill, Toward a New Theory of the Closely- Held Firm, 24 SeTON HaLl L. ReV. 603 (1993) stating that "[1]imited liability companies have long existed in Europe and Latin America ....").

203 MARKHAM \& HAZEN, supra note 28, at 17.

204 Ribstein, LLCs: Is the Future Here?, supra note 158, at 12.

205 Lovely, supra note 200, at 383 . The author goes on to note that this effort was apparently not successful. Florida rewrote its Limited Liability Company Act in 1998.

206 See, e.g., Thomas Earl Geu, Chaos, Complexity, and CoEvolution: The Web of Law, Management Theory, and Law Related Services at the Millennium, 66 TENN. L. REv. 137 (1998) (comparing the development of new business organizations to the evolution of living organisms).

207 Ribstein, Emergence, supra note 176, at 4.

208 Ribstein uses the analogy of the LLC being "spanked," to indicate that the birth is now complete. See Ribstein, Emergence, supra note 176, at 3. That is more aptly characterized as an event that is inherent in the process of the birth itself. I prefer to use the analogy of the briss, because this event is symbolic, and intended to show a true transformation in the baby. In the Jewish tradition, a child who 
[wherein] the IRS classified a Wyoming LLC as a partnership for tax purposes. ${ }^{, 209}$ The importance of this classification can not be understated:

By 1988, eleven years after the enactment of the Wyoming statute, only one other state (Florida) had enacted an LLC statute and there were only twenty-six LLCs in Wyoming. By the end of 1994, forty-six additional statutes had been passed and tens of thousands of LLCs had been formed. ${ }^{210}$

Professor Ribstein asserts that "[t]he explosion of LLC law in the few years since 1988 confirms not only the importance of the tax endorsement, but also the existence of a strong pent-up demand for this form of business." 211 Tax considerations appear to have been a key consideration in states' construction of their LLC statutes:

LLC statutory default rules have always been designed to help ensure that LLCs formed under the statute will be classified as partnerships for tax purposes. A business is taxed as a partnership under Subchapter $\mathrm{K}$ of the Internal Revenue Code if it is not a "corporation," which the Code defines to include "association." The rules for the types of firms that are "associations" for tax purposes ... provide that a business organization is a corporation and not a partnership if it has at least three of the following characteristics: continuity of life, centralized management, limited liability, and free transferability of interests. In order to help ensure that LLCs will be classified as partnerships for tax purposes, LLC statutes include default rules requiring that members consent to the transfer of management rights and that the firm dissolves upon the dissociation of a member. ${ }^{212}$

Federal income tax considerations may no longer be a factor in future revisions of LLC statutes. ${ }^{213}$ At this juncture, however, the plethora of business

died before his briss was essentially never born—a throwback to the days of high infant mortality among newborns.

209 Ribstein, Emergence, supra note 176, at 3.

210 Id.

211 Id. at 4

$212 I d$. at 5.

213 LLCs may also be assessed an income tax by the state in which they were created, although treatment for this purpose varies. Some states treat the LLC as a partnership in assessing state income tax. See, e.g., Fla. STAT. ANN. § 608.471 (West 2000). Other states treat the LLC as a corporation for this purpose. See Pa. Stat. AnN. tit. 15, § 8925(a) (West 1995); Mich. Comp. LaWs AnN. § 208.31 (West 1996). Texas assesses a "franchise tax" on the LLC, Tex. TAX CODE ANN. § 171.001(a)(2) (Vernon 1992). See also Norton L. Steuben, Choice of Entity for Real Estate After Check-the-Box and the Entity Explosion, 37 ReAL Prop. PROB. \& TR. J. 53 (2002):

Although the classification of the LLC for federal income tax purposes is straightforward under the check-the-box system, it may be unclear as a matter of state tax law or regulation. Not all states 
organizations has caused the IRS to throw its hands up in defeat and allow businesses organized in a form other than a corporation to choose how they wish to be classified for tax purposes. ${ }^{214}$

The popularity of the LLC prompted the creation of a Uniform Limited Liability Company Act, meant to guide states in the appropriate design of LLC statutes, which "was approved by the National Conference on Commissioners of Uniform State Laws in 1995." 215 This Uniform Act, however, has not proven to be as popular as the business form that inspired its creation. It has only been adopted in nine jurisdictions, ${ }^{216}$ and has been subjected to some sharp criticism by commentators. ${ }^{217}$

have adopted the check-the-box system. As a result, a disregarded LLC might be treated as a corporation for state tax purposes.

Id. at 59 .

214 See, e.g., Byron F. Egan, Choice of Entity Alternatives, 39 TEX. J. Bus. L. 379 (2004):

On December 18, 1996, the IRS issued Treasury Regulations Sections 301.7701-1, -2, and -3 (the Check-the-Box Regulations), which became effective January 1, 1997 and completely replaced the former classification regulations (discussed hereinafter). Entities will now have the assurance of either partnership or corporate classification under a set of default rules or the ability to make an election to obtain the desired classification.

$I d$. at 402 . Note, however, that "the IRS still requires certain prerequisites to be fulfilled prior to qualifying under the default rules or making a valid election." Id; see 26 C. F. R. § 301.7701-3(a) (2003) (stating "[a] business entity that is not classified as a corporation under $\S 301.7701-2(b)(1),(3),(4),(5),(6)$, (7), or (8) (an eligible entity) can elect its classification for federal tax purposes as provided in this section.).

215 Claire Moore Dickerson, Equilibrium Destabilized: Fiduciary Duties Under the Uniform Limited Liability Company Act, 25 STETSON L. REV. 417 (1995) [hereinafter Dickerson, Equilibrium Destabilized].

216 UnIF. LTD. LiabiLITY Co. ACT, Table of Jurisdictions Wherein Act Has Been Adopted, (2003). The jurisdictions are Alabama, Hawaii, Illinois, Montana, South Carolina, South Dakota, Vermont, West Virginia, and the Virgin Islands. Interestingly, Hawaii and Vermont were the last two states to adopt an LLC statute at all, and did not choose to do so until the ULLCA was completed. They were therefore among the first states to adopt the ULLCA, as other states had to decide whether to change their existing laws to conform with the provisions of the proposed Uniform Act.

217 See, e.g., Dickerson, Equilibrium Destabilized, supra note 215:

ULLCA is unsatisfactory in at least two ways. First, it is not supported by a clear understanding of why the LLC is considered a hybrid of the partnership and corporate forms. Second, it does not reflect a full analysis of the standards of performance currently applied to owners of a partnership versus those of a close corporation.

$I d$. at 421. Dickerson goes on to criticize ULLCA for going too far in eliminating fiduciary duties for members who are not designated as managers. Accord Callison \& Vestal, supra note 189, at 275-80. Perhaps the most thorough ULLCA rebuke can be found in Larry E. Ribstein, A Critique of the Uniform Limited Liability Company Act, 25 STETSON L. REv. 311 (1995) [hereinafter Ribstein, Critique]:

ULLCA makes many poor policy choices, including terms that are unsuited for informal firms, unnecessary mandatory rules, and rules that are inappropriately borrowed from other business forms. The drafting is often convoluted, complex and otherwise inept. . . Among ULLCA's more serious problems are the following: (1) Unclear definition of operating agreement; (2) excessive and unclear restrictions on the extent to which the operating agreement can waive the provisions of the act; (3) unclear provisions on the effect of the articles of organization; (4) unduly broad agency power to transfer real property; (5) questionable provision for contracting for personal liability; (6) 
In any event, this business form has enjoyed growing popularity, particularly in the last decade, not only among legislators, but among business founders as well. ${ }^{218}$ The LLC has become such an extraordinarily popular business form that "LLCs are gradually replacing corporations and limited partnerships as the leading business entity." 219 As has previously been noted, this popularity was spurred by the 1988 decision of the IRS that LLCs were to be taxed in the same way as partnership, ${ }^{220}$ and it is now possible to create an LLC in all 50 states. $^{221}$ Like the nexus of contracts theory, LLCs have also become a frequent topic of law review articles, ${ }^{222}$ and have even be-

unnecessary and perverse creditor-protection restrictions on distributions and compromise of contribution obligations; (7) questionable default veto power of members even in manager-managed firms; (8) unwieldy default duties to provide information to members; (9) confusing and overbroad fiduciary duties; (10) overbroad grounds for judicial dissolution; (11) confusion concerning effect of providing for a term; (12) wholly unworkable provisions on dissolution; and (13) unnecessary and perverse derivative remedy.

Id. at 387 .

218 Ribstein, LLCs: Is the Future Here?, supra note 158, at 12.

219 Id. (based on the author's examination of IRS filings from 2000-2002).

220 Id.

221 Ribstein, LLCs is the Future Here?, supra note 158, at 12 (noting that "[b]y 1996, every U.S. jurisdiction had an LLC statute"). Accord GREGORY \& HURST, supra note 163, at 809 ("By the end of 1996 all of the fifty states had adopted LLC statutes."). The statutes for the fifty states and Washington D.C. are ALA. CODE $\S \S 10-12-1$ to -61 (1993); AlASKA STAT. $\S ~ 10.50 .010-.995$ (Michie. 1994); ARIZ. REv. STAT. ANN. §§ 29-601 to -857 (West 1994); ARK. CODE ANN. §§ 4-32-101 to -1316 (Michie 1993); CAL. CoRP. CodE $\S \S 17000-17705$ (West 1995); Colo. Rev. STAT. ANN. §§ 7-80-101 to -1101 (West 1994); Conn. Gen. Stat. AnN. $\S \S 34-100$ to -242 (West 1995); Del. Code AnN. tit. 6, §§ 18-101 to 1107 (1993); D.C. CODE ANN. §§ 29-1301 to -1375 (1995); Fla. STAT. ANN. §§ 608.401-.514 (West 1993); Ga. Code ANN. §§ 14- 11-100 to -1109 (1995); Haw. Rev. Stat. AnN. §§ 428-101 to -1302 (Michie 1996); IDAHO CODE $\S \S 53-601$ to -672 (Michie 1995); 805 ILl. COMP. STAT. ANN. 180/1-1 to 60-1 (West 1995); IND. CODE ANN. §§ 23-18-1-1 to -13-1 (West 1994); IOWA CoDE ANN. §§ 490A.100.1601 (West 1995); Kan. Stat. ANN. §§ 17-7601 to - 7652 (1993); Ky. REv. STAT. ANN. §§ 275.001.455 (Michie 1994); La. Rev. StAT. ANN. §§ 12:1301-:1369 (West 1994); MASS. GEN. LAWS ANN. ch 156, §§ 1-69 (West 1995); MD. CodE ANN., CoRPS. \& Ass'NS §§ 4A-101 to - 1103 (1994); ME. Rev. STAT. ANN. tit. 31, §§ 601-762 (West 1994); Мich. CoMP. LAWS ANN. §§ 450.4101-.5200 (West 1995); Minn. StAT. ANN. §§ 322B.01-.960 (West 1995); Miss. CodE ANN. §§ 79-29-101 to -1201 (1994); Mo. ANN. Stat. §§ 347.010-.187 (West 1994); Mont. CODE ANN. §§ 35-8-101 to -1307 (1994); Neb. Rev. Stat. §§ 21-2601 to -2653 (Supp. 1994); Nev. Rev. Stat. ANN. §§ 86.010-.571 (Michie 1994); N.H. Rev. STAT. $\S 304-C: 1$-:85 ( 1994); N.J. STAT. ANN. §§ 42:2B-1 to -70 (West 1995); N.M. STAT. ANN. §§ 5319-1 to -74 (Michie 1994); N.Y. LTD. Liab. Co. LaW $\S$ 101-1403 (McKinney 1995); N.C. GEN. STAT. §§ 57C-1-01 to -10-07 (1994); N.D. CENT. CODE §§ 10-32-01 to - 155 (1993); OHIO REV. CODE ANN. §§ 1705.01-.58 (West 1994); OKLA. Stat. ANN. tit. 18, $\S \S 2000-2060$ (West 1995); OR. Rev. Stat. ANN. $\S \S$ 63.001-.990 (1994); PA. STAT. ANN. tit. 15, §§ 8901-8998 (West 1994); R.I. GEN. LAWS §§ 7- 16-1 to -75 (1994); S.C. CodE ANN. $\S 33-43-101$ to -1409 (Law. Co-op. 1995); S.D. CoDIFIED Laws $\S \S 47-34-1$ to -59 (Michie 1995); TenN. Code AnN. §§ 48-246- 101 to -602, 48-248-101 to -606 (1994); TeX. Rev. Civ. Stat. ANN. art. 1528n, §§ 1.01-11.07 (Vernon 1995); UTAH CODE ANN. §§ 48-2b-101 to -158 (1994); VA. CodE ANN. $\S 13.1-1000$ to -1123 (Michie 1993); VT. STAT. ANN. tit. 11, §§ 3001-3162 (1996); WASH. Rev. Code ANN. §§ 25.15.005-.902 (West 1995); W. VA. Code $\S \S 31-1 \mathrm{~A}-1$ to -69 (Michie 1994); WiS. STAT. ANN. §§ 183.0102-.1305 (West 1994); Wyo. STAT. ANN. §§ 17-15-101 to -143 (Michie 1995).

222 Leigh A. Bacon, "Freedom Of" or "Freedom From"? The Enforceability of Contracts and the Integrity of the LLC, 50 DUKE L.J. 1087 (2001), stating: "The sudden growth of limited liability com- 
come a topic of their own law school textbooks and treatises. ${ }^{223}$ Indeed, no modern business organizations textbook would be complete without some discussion of both concepts. ${ }^{224}$

\section{The Contractarian Nature of the Limited Liability Company}

\section{Ability of Parties to Avoid Fiduciary Duties Through an LLC}

The LLC, from its very incipiency, has been an entity with features that clearly evoke the nexus of contracts. Indeed, the very "heart of the LLC" 225 is a contract, the "operating agreement." 226 This is "a sort of consti-

pany (LLC) legislation in the past ten years has been accompanied by a corresponding amount of scholarship dedicated to the logistics, concerns, and implications of the limited liability company." See, e.g., Banoff, supra note 105; Cohen, supra note 17; Dickerson, Equilibrium Destabilized, supra note 215; Hamill, supra note 167; Hyde, supra note 1; Joseph L. Lemon, Jr., Just How Limited Is That Liability?: The Enforceability of Indemnification, Advancement, and Fiduciary Duty Modification Provisions In LP. LLP, and LLC Agreements in Delaware Law, 8 STAN. J.L. Bus. \& Fin. 289 (2003); Kleinberger, supra note 189; Lovely, supra note 200; Moore, supra note 87; Ribstein, LLCs: Is the Future Here?, supra note 158; Ribstein, Emergence, supra note 176; Ribstein, Critique, supra note 215; Victor Peterson and Alison N. Zirn, Corporate Directors, LLCs, and Liability: It's not Settled, but Caution is Advised, 12 AUG BUS. L. TODAY 57 (2003).

223 See, e.g., Stephen M. Bainbridge, Agency, Partnership ANd Limited Liability Companies (2003); LarRy E. Ribstein and Robert R. Keatinge, RibSTEIN and Keatinge on LIMITED LIABILITY COMPANIES (1998).

224 See, e.g., MELVIN A. EISENBERG, CORPORATIONS AND OTHER BuSINESS ORGANIZATIONS 498518 (8th ed. 2000) [hereinafter EISENBERG, CORPORATIONS] (discussing the limited liability company); Charles R.T. O'Kelley \& ROBERT B. THOMPSON, CORPORATIONS AND OTHER Business AsSOCIATIONS 62-63 (3d ed. 1999); MARKHAM \& HAZEN, supra note 28 (discussing the nexus of contracts theory at 14-15, and the advent and properties of limited liability company at 17, 21, and 78-89); see also Larry Ribstein, Corporations or Business Associations? The Wisdom and Folly of an Integrated Course, 34 GA. L. REv. 973 (2000). Ribstein argues:

[F]or the vast majority of our students the practice of business law will focus on closely held firms. Moreover, as we move into the twenty-first century, that practice will concern mainly unincorporated business forms, including partnerships, limited liability partnerships (LLPs), and limited liability companies (LLCs). ...it follows that only a fool would focus on corporations in the basic business course.

$I d$. Ribstein concedes that he will nevertheless continue to focus on corporations in his own basic business course, and concludes that law schools should offer an elective in unincorporated firms. Id. at 973 , 994.

225 Edward W. Feldman, Essential Elements of an Operating Agreement For a Law Firm Organized as an LLC, 16-APR CBA REC. 30 (2002); accord Lonnie Beard, The Small Business Entity Pass Through Act-The Birth of a Duck, 1993 ARK. L. NOTES 15, 17 (1993).

226 See, e.g., WYO. STAT. ANN. § 17-15-104(x) (Michie 1995):

(a) Each limited liability company organized and existing under this act may:

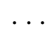


tution for the entity that allows the owners ... with limited exceptions, to define their relations with each other and with third parties and to prescribe rules for operation and management of the entity."227 The close proximity between the development of that theory and the creation of the LLC raises the temptation to suggest that there may have some direct connection between them. It is not so hard to imagine that, among all the state legislators in Wyoming in 1977, perhaps there was an economist or a business lawyer-the kind of person who might read Jensen and Meckling's article in the Journal of Financial Economics and take from it the inspiration to propose a new kind of business that would exactly fit the theory found therein. There is absolutely no evidence of such a connection, however, and the more likely possibility is that both the article and the new business form were simply coincidental responses to the common business and economic conditions of the time.

Many legal scholars have examined the ability of the LLC members to modify or waive the fiduciary duties of the LLC's managers. ${ }^{228}$ Some have either implicitly suggested that the LLC is a nexus of contracts, ${ }^{229}$ or explicitly argued that the LLC should be treated as one. ${ }^{230}$ The LLC has succeeded in avoiding the unlimited liability of a partnership while also avoiding the choice between the structural rigidity and double taxation of a corporation

(x) Make and alter operating agreements, not inconsistent with its articles of organization or with the laws of this state, for the administration and regulation of the affairs of the limited liability company.

Various additional sections of the Wyoming statute permit or require that a wide variety of details be laid out in the operating agreement, such as management structure, relations between managers and other members, and division and allocation of profits. See also FLA. STAT. ANN. §§ 608.402(24) (West 1993) (defining the operating agreement as "written or oral provisions that are adopted for the management and regulation of the affairs of the limited liability company and that set forth the relationships of the members, managers, or managing members and the limited liability company").

227 Feldman, supra note 225, at 30. The operating agreement can be a quite lengthy document. One unreported case, Niki Development Corp. v. HOB Hotel Chicago Partners, L.P., 2003 WL 1712563 (N.D. Ill. 2003) refers to an operating agreement that was apparently 99 pages long, based on the court's reference to the presentation of that page of the document as evidence that the document had been signed by the parties.

228 See, e.g., Callison \& Vestal, supra note 188 (examining the provisions afforded in various states and under the ULLCA by which waiver of fiduciary duties by members of an LLC is permitted or prohibited); Dickerson, Equilibrium Destabilized, supra note 215 (criticizing provisions within the Uniform Limited Liability Company Act that permitting LLC members to set varied levels of fiduciary duties); Moore, supra note 87 (criticizing the decision of the Ohio Court of Appeals for permitting members of an LLC to waive fiduciary duties); see also Peterson, supra note 222 (examining the possibility that directors of a corporation that manages an LLC may yet have fiduciary duties to LLC members, even where members have waived fiduciary duties with respect to the LLC itself).

229 See, e.g., Cohen, supra note 17. Cohen asserts that "The LLC in many ways represents the latest and perhaps most audacious attempt by contractarians to remove from commerce the 'shackles' of the state," Id. at 433, and examines various questions raised by the existence of the LLC, including the possibility that the LLC should be treated as a contract among all parties involved. Id. at 486-490.

230 See, e.g., Ribstein, Emergence, supra note 176. 
and the far greater structural rigidity of the Subchapter S corporation. A feature common to LLC statutes that is even more important to this analysis is the fact that every state now recognizes foreign LLCs. ${ }^{231}$ As the Prefatory Notes to the ULLCA indicate, "state limited liability company acts display a dazzling array of diversity." 232 Some states permit every aspect of the LLC's existence and operation-including such particulars as fiduciary duties to investors-to be reduced to contractual language in an operating agreement:

The most controversial aspect of fiduciary duties in the LLC context is that many statutes grant members the power to waive fiduciary duties in their entirety. Some statutes, such as New Jersey's, have no express fiduciary standards but grant express authorization for contractual modifications of judge-made fiduciary doctrines. Other state statutes have fiduciary standards proscribed as default provisions, allowing avoidance of those standards only if the avoidance is contracted for in the original LLC agreement. ${ }^{233}$

As one commentator notes, "LLCs are creatures of statute. Consequently, to the extent that the statutes describe the extent of fiduciary duties, they control." ${ }^{234}$ The statutes are themselves both widely varied and very flexible. ULLCA, for example "does describe fiduciary duty, but permits the parties to define it further, subject to a mandatory threshold of good faith." ${ }^{, 235}$ However, only a handful of states have adopted the ULLCA. By contrast, "[t]he forty-one states which have adopted non-ULLCA-based LLC statutes deal with the fiduciary duties of participants in a wide variety of ways." ${ }^{236} \mathrm{~A}$ number of states provide no language supporting a requirement of fiduciary duties, despite having "statutory provisions governing the fiduciary duties of partners in general partnerships, general partners in limited partnerships, and directors and officers in corporations." 237 The authors of the ULLCA

231 See, e.g., DEl. CODE ANN. tit. 6, §§ 18-901 - 18.902; Fla. STAT. AnN. § 608.4082(1); Wyo. STAT. ANN. § 17-15-132.

232 UnIF. LTD. Liability Co. ACT, Prefatory Note, at i (2003).

233 Cohen, supra note 17, at 461. The author goes on to note that "a number of states do not expressly mention the issue of fiduciary duties in their statutes," leaving the issue open for contractatrians and non-contractarians to argue over, and for courts to ultimately decide.

234 Dickerson, Equilibrium Destabilized, supra note 215, at 420-21. This sentiment has been echoed by a number of courts. See, e.g., Halley v. Barnabe, 24 P.3d 140, 145 (Kan. 2001) ("Limited liability companies became creatures of the Kansas statutes commencing with the enactment of the Kansas Limited Liability Company Act"); Alexander v. Minton, 855 So.2d 94, 97 (Fla. 2d Dist. Ct. App. 2003) (noting that LLC's "are wholly creatures of statute").

235 Id. at 421.

236 Callison \& Vestal, supra note 189, at 281.

237 Id. at 281. According to the authors, "[t]he Arizona, Kansas, Maryland, Nebraska, New Mexico, Nevada, Texas, Utah, and Wyoming LLC acts make no reference to member or manager fiduciary 
itself remark that "this lack of uniformity manifests itself in basic but fundamentally important questions, such as: what are the fiduciary duties of owners and managers to a company and each other . . . and are any or all of these and other rules simply default rules that may be modified by agreement or are they nonwaivable."238

As Ribstein predicted:

$[\mathrm{P}]$ articularly given the blurred distinctions between members and managers in LLCs, statutes cannot completely define members' and managers' duties. Courts will have to fill in the blanks left by statutes and agreements, having due regard for the unique attributes of LLCs as distinguished from other types of business associations. ${ }^{239}$

To this end, it appears that many courts are, thus far, willing to uphold waivers of fiduciary duties.

In Lynch Multimedia Corp. v. Carson Communications., $L L C{ }^{240}$ the District of Kansas granted summary judgment against a claim for breach of fiduciary duty. In that case, Lynch and Carson were both members of a joint venture LLC called CLR Video, which was in the cable television business. ${ }^{241}$ The operating agreement for the LLC contained two provisions at issue, one of which required members who became aware of an opportunity to attain another cable television business to "offer" it to the company; ${ }^{242}$ the other of which expressly permitted members to "engage independently or with others in other business ventures of every nature and description.",243 When Carson did eventually come across opportunities to attain some other cable television businesses, he informed Lynch about it. ${ }^{244}$ When Lynch did not respond conclusively, Carson pursued them on his own. ${ }^{245}$ Lynch sued, and the District Court found summary judgment in favor of Carson, ${ }^{246}$ concluding that " $[\mathrm{u}]$ nder Kansas law, the members of a limited liability company may expand or restrict their duties and liabilities by the terms of their agreement." ${ }^{247}$ The court determined that Carson had discharged his responsibility to make the offer when Carson told Lynch about the opportunity;

\footnotetext{
duties. These states therefore leave the duty question to the operating agreement or to judicial commonlaw development." Id. at n. 49 .

238 UNIF. LTD. LiabiLITY Co. ACT, Prefatory Note, at i (2003).

239 Ribstein, Emergence, supra note 176, at 21; but see Kleinberger, supra note 189 at 17 (asserting that "the LLC does not create gaps in judge-made law; it merely provides opportunities for judges to rearticulate established public policies in the light of new circumstances").

240102 F. Supp. 2d 1261 (D. Kan. 2000).

241 Id. at 1262.

242 Id.

$243 I d$. at 1263.

244 Id.

245 Id.

$246 I d$. at 1265.

247 Id.
} 
and that Carson was then free to pursue the opportunity pursuant to the section of the operating agreement that permitted members to engage in their own business ventures. Such a conclusion could not have been reached if this business was either a corporation or a partnership, for in either of those cases, Carson would have been a fiduciary, bound by a non-waivable duty not to compete. ${ }^{248}$

In a similar case, McConnell v. Hunt Sports Enterprises, ${ }^{249}$ "the appellate court for the Tenth District of Ohio joined the state of Delaware and other states when it found that members of a limited liability company (LLC) could choose to opt-out of their common law or statutory fiduciary duties to one another." ${ }^{, 250}$ In this intriguing set of facts, a group of individuals formed an LLC called the Columbus Hockey League (CHL) for the purpose of acquiring an NHL team. ${ }^{251}$ When LLC member McConnell succeeded in acquiring an NHL franchise, litigation commenced. ${ }^{252}$ Ultimately, the trial court directed a verdict in favor of McConnell, and "[t]he appellate court upheld the trial court's decision and found that 'an operating agreement of a limited liability company may, in essence, limit or define the scope of the fiduciary duties imposed upon its members.",253

In McGee v. Best, ${ }^{254}$ a state appellate court in Tennessee went so far as to deny the existence of fiduciary duties for an LLC created in that state. When a member of such an entity alleged that his firing constituted a breach of fiduciary duty, the court upheld the finding of the trial court that:

[T] he Tennessee Limited Liability Corporation Act ... does not create a fiduciary duty between members of an LLC. An LLC is a creature of statute, and any duty which members owe must be set forth in the statute. However, the Tennessee LLC Act does not create a fiduciary duty between members of an LLC. Therefore, Plaintiff's cause of action based upon a fiduciary obligation owing to him individually does not state a cause of action recognized under the Tennessee LLC Act. ${ }^{25}$

Not all states have taken so permissive an approach. In New York-the birthplace of Justice Cardozo's exacting standard from Meinhard $v$.

\footnotetext{
248 See supra note 78-107 and accompanying text for discussion of fiduciary duties.

249725 N.E.2d 1193 (Ohio Ct. App. 1999).

250 Moore, supra note 87, at 184.

251 Id. at 197.

252 Presumably the Columbus Blue Jackets, which, at the time of this writing, is a sub-par professional hockey team, ranked 14th out of the 15 teams in the National Hockey League's Western Conference. ESPN NHL 2003-2004 Standings, http://sports.espn.go.com/nhl/standings?group=conference\& column=playoffs (last visited Friday, April 15, 2004).

253 Moore, supra note 87, at 199.

254106 S.W.3d 48 (Tenn. Ct. App. 2002).

$255 I d$. at 57.
} 
Salmon ${ }^{256}$-one court recently ruled that LLC members must be held to the same exacting standards as any other cooperative business venture. In Salm v. Feldstein, ${ }^{257}$ the parties were members and co-managers of a Honda Dealership organized as an LLC. The plaintiff alleged a breach of fiduciary duty based on the failure of the defendant to notify the plaintiff of a third party's offer to purchase the enterprise. ${ }^{258}$ The defendant countered that "fiduciary duty does not lie between partners or managers in a limited liability company." ${ }^{259}$ The court agreed that "the Limited Liability Company Law gives broad discretion to the parties to shape their operating agreement, ${ }^{, 260}$ and noted that this statute had "no provision which explicitly imposes or negates a fiduciary duty." ${ }^{261}$ Nevertheless, the court determined that the relative position of the parties demanded the imposition of fiduciary duties:

[T] he law does provide that a "manager shall perform his or her duties as a manager . . . in good faith and with the degree of care that an ordinary prudent person in a like position would use under similar circumstances ..." In addition, partners in joint ventures, however constituted, owe one another a fiduciary duty of loyalty. The duty includes an obligation not to favor one's own interests over those of the joint venture, to unfairly manipulate or control corporate processes to retain control or to appropriate for oneself an opportunity that belongs to the joint venture. A partner has a fiduciary obligation to other partners in the organization and owes a duty of individual and undiluted loyalty to those whose interests the fiduciary is to protect. ${ }^{262}$

The ultimate end of these variations is that the formation of LLCs, much like the formation of corporations, will gravitate towards those states that offer the terms perceived to be most favorable to the parties responsible for this formation. Delaware appears intent to maintain its claim as the leading location for the formation of new businesses. Cohen notes that "Delaware represents the boldest and most powerful push toward a private contractualist model of the firm." ${ }^{263}$ Indeed, in Elf Atochem Inc. v. Jaffari, ${ }^{264}$ the Delaware Supreme Court stated that "only where the agreement is inconsistent

256 See supra note 89 and accompanying text.

257 No. 11940-03 (N.Y. App. Div. Aug. 20, 2004).

258 Id. at 4.

259 Id.

260 Id.

261 Id.

262 Id. (emphasis added). The court nevertheless upheld the dismissal of the cause of action for lack of evidence to show that the alleged firm offer had, in fact, been made.

263 Cohen, supra note 17 , at 472.

264727 A.2d 286 (Del. 1999) (holding that an LLC was bound by its operating agreement against at attempted derivative suit, despite the fact that the LLC did not yet exist when the agreement was executed). 
with mandatory statutory provisions will the members' agreement be invalidated." ${ }^{265}$ This is a fairly strong statement, given that " $[\mathrm{t}]$ he Delaware statute has perhaps the greatest emphasis on the freedom to contract around fiduciary duties; this statute explicitly warns the courts not to void these contracts.",266

While it is true that the LLC might more appropriately be categorized as a nexus of contracts, based on the exceptional flexibility available to parties to the formation of such a business, it would be a very weak argument to suggest that the LLC was devised by state legislatures with the intent of creating a truly contractarian business form. Professor Ribstein asserts that "the original Wyoming statute was hardly more than a cut-andpaste from Wyoming's limited partnership and corporation statutes with a smattering of provisions from Wyoming's general partnership statute. ${ }^{267} \mathrm{He}$ further asserts that " $[\mathrm{t}]$ he growth of LLC statutes has been spurred largely by state bar committees rather than by independent legislative initiatives."268 Others make a compelling case that the predominant "theory" motivating state legislatures in enacting LLC statutes was the theory that they would thereby attract business to their respective states. They explicitly assert that "it would be a mistake to treat the popularity of the LLC form as evidence that an underlying theory of the LLC has been well articulated or generally accepted." 269 At least one commentator, however, continues to argue "that the LLC's popularity stems merely from its tax status and that the whole purpose of the LLC is to avoid taxes.,"270

\section{Transferability of Business Forms and Recognition of Foreign LLCs}

Although the ULLCA contemplates the possibility of businesses shifting from one form to another, it only addresses the potential conversion of partnership or limited partnership to a limited liability company. ${ }^{271}$ Ribstein comments that "[s]everal LLC statutes also provide for conversions of general and limited partnerships to LLCs." ${ }^{272}$ Another way that an existing

265 Id. at 288.

266 Cohen, supra note 17, at 461; see also DEL. CoDE ANN. tit. 6, § 18-306 (1993) (the LLC operating agreement may provide for penalties or consequences for members upon nonfeasance or other events specified therein); id. $\S 18-405$ (same provision with regard to managers).

267 Ribstein, Emergence, supra note 176, at 4.

268 Id. at 34.

269 Callison \& Vestal, supra note 189, at 275.

270 Cohen, supra note 17 , at 449.

271 UNIF. LTD. LiabiLiTy Co. ACT § 902-03 (2003).

272 Ribstein, Emergence, supra note 176, at 33. See, e.g., DEL. CODE ANN. tit 6, § 17-219:

Approval of conversion of a limited partnership. 
business might become an LLC is to merge into one. With regards to mergers, Ribstein notes that "[v]irtually all LLC statutes allow mergers among LLCs and often between LLCs and other types of business entities . . [and] about one-third of the jurisdictions generally allow mergers between LLCs and other types of business entities. ${ }^{273}$ Ribstein notes, however, that "it may not be clear what the effects are of a transaction that fails to comply with statutory formalities . . . [and that] cross-entity merger and conversion provisions may not fully integrate with the statute governing the non-LLC entity.",274

Finally, all states now recognize foreign LLCs, meaning that nothing stands in the way of a business forming itself as an LLC in the state with the most flexible rules, and including a forum selection clause in its operating agreement to insure that disputes are settled in that state, ${ }^{275}$ and a choice of law clause as well. ${ }^{276}$

After examining possible scenarios that might arise with LLCs engaging in third-party transactions in foreign states, Ribstein logically concludes that "[i]n general, when deciding which state's law to apply, the courts should take into account both the costs and benefits of applying formation state law," 277 and notes that "[e]nforcing formation state law enhances predictability and often is consistent with the parties' expectations.",278

\section{IMPLICATIONS OF THE LIMITED LIABILITY COMPANY FOR THE LEGAL STATUS OF CORPORATIONS}

The most significant problem that arises in supporting any assertion regarding the impact of the LLC lies in pinning down the nature of the LLC itself. This difficulty is reflected in the prefatory notes to the UCLLA,

\footnotetext{
(a) Upon compliance with this section, a domestic limited partnership may convert to a corporation, a statutory trust, business trust or association, a real estate investment trust, a common-law trust or any other unincorporated business, including a general partnership (including a limited liability partnership) or a foreign limited partnership (including a foreign limited liability limited partnership) or a limited liability company.

273 Ribstein, Emergence, supra note 176, at 33.

274 Id.

275 Exactly such a provision that was at issue in Elf Atochem, 727 A.2d 286 discussed supra notes 264-65 and accompanying text. In that case, the Delaware Supreme Court upheld a choice-of-law provision in the operating agreement that required disputes between members to be settled in the courts of

276 Ribstein, Emergence, supra note 176, at 34.

LLCs that want to do business as "foreign LLCs" are governed by their formation state law at least to the extent provided in the applicable foreign LLC statute. Although all LLC statutes require foreign LLCs transacting business in the state to register or qualify, the choice-of-law provisions apply to foreign LLCs irrespective of registration or qualification.

277 Id. at 38 .

278 Id.
} California. 
which note that "[s]ince most state limited liability company acts are in their infancy, little if any interpretative case law exists, ${ }^{, 279}$ and further concede that "[e]ven when case law develops, it will have limited precedential value because of the diversity of the state acts. ${ }^{, 280}$ However, while this comment does not seek to make any final determination as to whether the LLC is, in fact, a nexus of contracts entity, it does argue that the existence of the LLC disproves the nexus of contracts theory of corporations irrespective of the true nature of the LLC with regard to this theory.

\section{A. All Business Organizations Are Cost Avoidance Systems}

Although the LLC is generally discussed as an entity that captures the advantages offered by other business forms ${ }^{281}$ it might be equally appropriate to characterize it as an entity that avoids the disadvantages of all other business forms. Such a discussion might be a useful tool in determining the nature of the LLC without making an excessive effort to tie its characteristics to forms that existed previously. For example, contractarians would very much like to claim that the LLC is a business entity that avoids mandatory fiduciary duties. If they are correct in this assertion, then the LLC is unlike any other previously existing business form. ${ }^{282}$ Therefore, rather than asserting that an LLC is "like a partnership" in some ways, and "like a corporation" in other ways, I will continue to regard the LLC as a unique form that is "unlike a partnership" in that it avoids the disadvantages of a partnership, and "unlike a corporation" in that it avoids the disadvantages of a corporation.

Indeed, any discussion of the benefits to be gained by employing a particular kind of business form is based on a false premise. No business form actually provides benefits; they only reduce or avoid costs. As Coase pointed out above, if there were no transaction costs involved in the conduct of business, there would be no need for any kind of business organization whatsoever. ${ }^{283}$ Every person seeking to sell a service or manufacture and sell a product would be a sole proprietor. Each entrepreneur seeking to produce and market a new product would acquire loans to pay for the ven-

\footnotetext{
279 UNIF. LTD. LiabiLITy Co. ACT, Prefatory Note, at i (2003).

$280 I d$.

281 See, e.g., Ribstein, Emergence, supra note 176, at 2-3; Kleinberger, supra note 189, at 15; Cohen, supra note 17 , at 447.

282 Technically, no fiduciary duties are owed to anyone by the proprietor of a sole proprietorshipthat is, a "business in which one person owns all the assets, owes all the liabilities, and operates in his or her personal capacity." BLACK's LAW DiCTIONARY 653 (2d Pocket ed. 2001). However, this is only because there is simply no other person to whom such duties could be owed in such an arrangement.

283 See supra notes 117-118 and accompanying discussion.
} 
ture ${ }^{284}$ would hire on the spot all of the employees necessary for production; and would purchase and sell all of the required materials on the open market. There would be no need for the creation of a partnership, a corporation, or some other form of limited liability business organization. If the product was unable to compete, the business would fail, and the entrepreneur would be held liable for whatever breaches of contract would result. If the product is defective and causes injury, then the entrepreneur would be required to pay to compensate the damage; and if the cost is too high, once again the business would fail. Such a business would truly and undeniably be a nexus of contracts.

But, as noted above, transaction costs do exist in the real world, ${ }^{285}$ and those costs can be reduced through the formation of a formal business organization - a device that ties people together in long-term commitments to their roles and, more importantly, provides potential investors and creditors with a more appealing arrangement for the security of their resources. The business organization provides no benefits with respect to the conduct of the business itself. Simple logic suggests that an entrepreneur who piecemeal contracts out every aspect of his production and sales cannot increase those sales by one penny simply by dint of arranging his business in a more acceptable form. The only thing that she can accomplish thereby is to reduce her costs of doing business-which will naturally leave more resources for advertising, or quality control, or increased production, or to allow for a reduced price. But this reduction in transaction costs comes at a price of its own, and that price depends on the business form that the entrepreneur chooses.

In any business organization, the entrepreneur must surrender some autonomy. If she enters into a partnership, she will be powerless to make changes to the business without the consent of a majority of partners; ${ }^{286}$ and she will be held personally liable for the debts that other partners may incur upon the business. By incorporating, she escapes from that imposition of liability, but may be subject to compounded or higher taxes, strict regulations, and the imposition of fiduciary duties to stockholders of the corporation. In each of these combinations, some potential cost is avoided, but only upon the acceptance of a different potential cost.

Consider this example: I walk up to you and hit you in the head with a stick. You say "stop that!" and I reply, "I will, if you give me five dollars." If you decide that it is worth five dollars to you not to be hit with a stick

284 The requisite loans would not come from a bank, as banks, like corporations, exist to reduce agency costs. The lenders would not necessarily assess a set interest on their loans-they might instead entitle the lender to a percentage of the profits, and even a voice in the operations of the business.

285 See supra notes 93-95 and accompanying text for discussion of the conceptual world without transaction costs.

286 See supra note 164. 
again, and you therefore give me the five dollars to get me to stop, have you really purchased a benefit? Are you any better off than you would have been if you had pursued some other solution, such as running away, hitting me back, or calling the police? Only two things are certain in the above scenario. First, if I am an honorable businessman, then I will not hit you again (and if I do, then you may add breach of contract to the battery claim you would already have against me). Second, you are out five dollars. You have gained nothing, but have merely avoided the burden of being hit by substituting the more palatable burden of having fewer dollars in your pocket to buy the things you want.

For this reason, reference to the acquisition of "limited liability" is a great misnomer. The more accurate, if also more cumbersome, term would be "avoidance of unlimited liability." Avoidance of some amount of liability, therefore, is no benefit, but merely a way around what would otherwise be a potential cost. ${ }^{287}$ In the same vein of thought, for a company to be taxed as a partnership, a Subchapter S corporation, or (now) an LLC is not a benefit, but merely an avoidance of a higher tax cost. But, like the five dollars that you are willing to pay to avoid being hit, persons who wish to do business are willing to pay some kind of price such as unlimited liability for the wrongs committed by a business partner, or higher taxes, or restrictions on their management plan, or complex paperwork. The benefit that this sacrifice buys is the avoidance of transaction costs, because such costs make it impossible to conduct business on a large scale outside the structure of some business entity.

Under this approach, the limited liability company ought not be described as an effort to combine the benefits of other business forms, because business forms have no benefits. The LLC is therefore nothing more than a form designed to avoid as many costs as possible. It largely succeeds. Through this form, entrepreneurs can avoid most of the major burdens of doing business - transaction costs, unlimited liability, additional taxation, and imposition of mandatory fiduciary duties. The burdens that remainfiling with the state and meeting some reporting requirements-are minimal, and at any rate are no greater than similar requirements already imposed on most other business forms. The greatest danger inherent in attempting to characterize the LLC as a combination of attributes held by other business forms is that such a characterization inevitably places the LLC under the heavy burden of common law precedent as applied to these other forms.

287 For a discussion of the general social and economic benefits purported to flow from the availability of limited liability to businesses, see EASTERBROOK \& FisCHEL, supra note 1, at 40-44. 


\section{B. Parties Who Now Choose to Form a Corporation Instead of a Limited Liability Company Have Chosen to Accept the Associated Fiduciary Duties}

Because parties seeking to form a new business with the characteristics of a pure "nexus of contracts" have this option available through the LLC, it can be assumed that those seeking to form a traditional corporation have chosen to accept the duties of operating under a business form more heavily constrained by principles that exist beyond the four corners of the documents by which the corporation is created and allowed to exist. In the modern business world, no competent businessperson would initiate a major commercial venture without first consulting with an attorney and no competent attorney in any field of law related to business would be unaware of the existence of the LLC as a particularly enticing business form.

\section{Transferability of Business Forms}

As noted above, no legal mechanism stands in the way of the owners of an existing corporation reforming their business organization into an LLC. Indeed, the ULLCA contemplates the possibility of businesses shifting from one form to another. ${ }^{288}$ A counter-argument might be made that the practical difficulty of making such a transformation increases exponentially as the size and complexity of the corporation in question increases. However, so long as such a transition is legally possible, decision-making based on the nexus of contracts theory with regard to the duties of traditional corporations should nevertheless be abandoned. The interest in uniform and predictable application of the laws combined with the relatively minor potential harm inherent in continuing to assign fiduciary duties to corporate managers both support this outcome. ${ }^{289}$

Despite recognizing that the development and proliferation of the LLC as a business form is a major event in the history of business organizations, theorists arguing both sides of the issue have ignored the possibility that the existence of the LLC has any effect whatsoever on the application of the nexus of contracts theory to corporations. Arguments instead center on the

\footnotetext{
288 See, e.g., UNIF. LTD. LIABILITY Co. ACT $\S 902-903$ (2003) (allowing a partnership or a limited partnership to convert to a limited liability company through a filing with the secretary of state; specifying that the new entity thereby created will maintain both the possessions and the obligations of the old entity; and specifying that partners to the old entity become members to the new entity).

289 Concededly, this argument would lose much of its strength if the suggested distinction between LLCs and corporations were to result in the assessment of even more stringent fiduciary duties on corporations.
} 
question of whether fiduciary duties ought to be attributed to any business form, or to all business forms. ${ }^{290}$

D. Irrelevance of the Actual Nature of the LLC

If the corporation really is a nexus of contracts entity, then the LLC is redundant. After all, if courts were to follow the nexus of contracts theory, they would cease to apply fiduciary duties to corporations, and would necessarily fall back on the law of contract to determine how disputes between parties to the corporation should be settled. The corporation would then be able to arrange its affairs with respect to its constituent parties in whatever manner it desired, and would be indistinguishable from an LLC having the same ability. However, it is a venerable canon of statutory construction "that courts should 'avoid a reading of statutory language which renders some words altogether redundant." ${ }^{291}$ Therefore, where a state enacts a statute creating a new form of business organization, the courts must presume that the state intended for this new form to have characteristics that distinguish it from all existing forms. As noted above, courts have established heightened fiduciary duties for close corporations. Many LLCs resemble close corporations, but this has not prevented courts from honoring waivers of corporate-type fiduciary duties found in their operating agreements. $^{292}$

If the LLC itself is not truly a nexus of contracts and is, in fact, determined to be subject to fiduciary duties as an enterprise (as the court in Salm v. Feldstein determined), ${ }^{293}$ then the continued treatment of corporations as an enterprise subject to fiduciary duties seems all the more reasonable by comparison. If it is appropriate to lay such duties on an entity that much more closely resembles a nexus of contracts, then it is impossible for a less contractarian entity to expect to avoid those duties. A simple metaphor is a children's amusement park ride with a posted height limit. If the five-foot tall teen is told he is too tall to ride, his six-foot tall older brother need not even step in the line.

The need for certainty underscores the irrelevance of the true nature of the LLC. Although there may be great utility to the establishment of a true nexus of contracts entity, there exists a degree of stability and reassurance

290 See supra notes 126-140 and accompanying text for discussion of the dispute between contractarians and anticontractarians.

291 Cole v. Burns International Security Services, 105 F.3d 1465, 1470 (D.C. Cir. 1997) (citing Gustafson v. Alloyd Co., 513 U.S. 561, 574 (1995) and United States v. Menasche, 348 U.S. 528, 538539 (1955) (each holding that statutory language in different sections of an act had to be interpreted so that each section would be given separate effect)).

292 See supra notes 238-250, 255-258 and accompanying text.

293 Supra note 253. 
in the continued assessment of such duties to corporations, in the face of uncertainty about the contractarian nature of the LLC.

\section{CONCLUSION}

The uniform availability of the LLC as a business form should eliminate any reason for treating the corporation as anything other than an enterprise-a separate entity whose existence calls into play certain duties owed to it by its managers, irrespective of what is laid out on paper. ${ }^{294}$ One commentator suggests that political concerns will determine which view the courts ultimately take, predicting that "American fears of concentrated wealth will not be placated by the legislature defining an LLC as a contract between two private parties." ${ }^{, 295}$ This comment disagrees, and expects that courts will at least treat smaller LLCs-those that are akin to close corporations in size and scope-as though they are mere contractual agreements between the members.

It is only when LLCs approach the scale of billion-dollar businesses, with third parties purchasing some form of interests in the LLC that are distinguishable from the current membership, that courts should determine that this business form has entered the realm of those corporate forms that should be assessed as having fiduciary duties. At that point, courts will naturally arrive at approximately the same distinction that already separates close corporations from their publicly held counterparts. Even then, every dispute involving the duties owed one another by members of an LLC should be reviewed on a case-by-case basis, for (unless boilerplate LLC formation language comes into vogue) each LLC will be governed by a unique document that represents the desires of the parties involved. But for those who choose to maintain or create new corporations, the courts should not hesitate to assess the full array of traditional fiduciary duties. Two possibilities support this outcome. Either the corporation is not a nexus of contracts entity because the LLC is one, and the law would not allow redundant business forms; or the corporation was never a nexus of contracts entity because even the more contractarian LLC is also not one.

It is entirely possible that the crucible of litigation will reveal the LLC to be the true nexus of contracts entity that contractarians claim it is, and perhaps courts ought to permit the experiments in this direction by states such as Delaware to go forward unhindered. In so doing, the benefits and burdens of permitting such a structure to exist will be exposed, and the contention of the contractarians that such a form will self-regulate to the best interests of all parties involved will be put to the test. Should this experi-

\footnotetext{
294 See supra notes 172-177 and accompanying text.

295 Cohen, supra note 17 , at 433.
} 
ment succeed, contractarians will have their nexus of contracts entity, and anti-contractarians will still be able to point to the corporation as proof that even the nexus of contracts entity is only a creature of the state, and not necessarily the best practicable arrangement.

Based on the above factors, courts before whom the issue is raisedand legislatures and legal scholars in general-should recognize that the existence of the limited liability company as a business form renders obsolete the argument that a nexus of contracts model should apply to the corporate business form. 